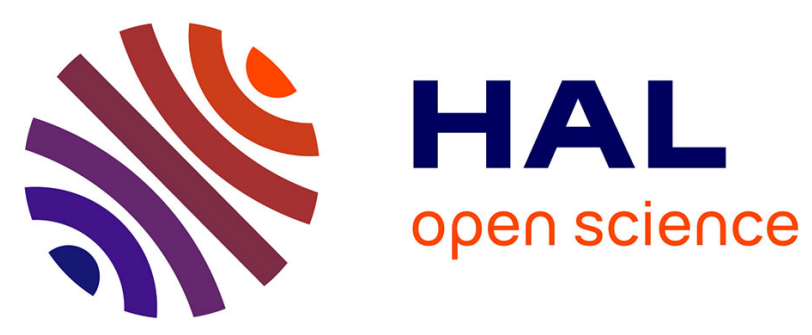

\title{
Petrogenetic implications of chromite-seeded boninite crystallization experiments: Providing a basis for chromite-melt diffusion chronometry in an oxybarometric context
}

Daniel A. Coulthard Jr, Georg F. Zellmer, Akihiko Tomiya, Sébastien Jégo, Raimundo Brahm

\section{To cite this version:}

Daniel A. Coulthard Jr, Georg F. Zellmer, Akihiko Tomiya, Sébastien Jégo, Raimundo Brahm. Petrogenetic implications of chromite-seeded boninite crystallization experiments: Providing a basis for chromite-melt diffusion chronometry in an oxybarometric context. Geochimica et Cosmochimica Acta, 2021, 297, pp.179-202. 10.1016/j.gca.2021.01.017 . insu-03123506

\section{HAL Id: insu-03123506 \\ https://hal-insu.archives-ouvertes.fr/insu-03123506}

Submitted on 28 Jan 2021

HAL is a multi-disciplinary open access archive for the deposit and dissemination of scientific research documents, whether they are published or not. The documents may come from teaching and research institutions in France or abroad, or from public or private research centers.
L'archive ouverte pluridisciplinaire HAL, est destinée au dépôt et à la diffusion de documents scientifiques de niveau recherche, publiés ou non, émanant des établissements d'enseignement et de recherche français ou étrangers, des laboratoires publics ou privés. 


\section{Journal Pre-proofs}

Petrogenetic implications of chromite-seeded boninite crystallization experiments: Providing a basis for chromite-melt diffusion chronometry in an oxybarometric context

Daniel A. Coulthard Jr, Georg F. Zellmer, Akihiko Tomiya, Sébastien Jégo, Raimundo Brahm

PII: S0016-7037(21)00039-9

DOI: https://doi.org/10.1016/j.gca.2021.01.017

Reference: GCA 12047



To appear in:

\section{Geochimica et Cosmochimica Acta}

Received Date:

12 August 2020

Revised Date:

13 January 2021

Accepted Date:

18 January 2021

Please cite this article as: Coulthard, D.A. Jr, Zellmer, G.F., Tomiya, A., Jégo, S., Brahm, R., Petrogenetic implications of chromite-seeded boninite crystallization experiments: Providing a basis for chromite-melt diffusion chronometry in an oxybarometric context, Geochimica et Cosmochimica Acta (2021), doi: https:// doi.org/10.1016/j.gca.2021.01.017

This is a PDF file of an article that has undergone enhancements after acceptance, such as the addition of a cover page and metadata, and formatting for readability, but it is not yet the definitive version of record. This version will undergo additional copyediting, typesetting and review before it is published in its final form, but we are providing this version to give early visibility of the article. Please note that, during the production process, errors may be discovered which could affect the content, and all legal disclaimers that apply to the journal pertain.

(C) 2021 Elsevier Ltd. All rights reserved. 
Petrogenetic implications of chromite-seeded boninite crystallization experiments:

Providing a basis for chromite-melt diffusion chronometry in an oxybarometric context

$4 \quad{ }^{1 *}$ Daniel A. Coulthard Jr., ${ }^{1}$ Georg F. Zellmer, ${ }^{2}$ Akihiko Tomiya, ${ }^{3}$ Sébastien Jégo, ${ }^{1}$ Raimundo

5 Brahm

$6{ }^{1}$ Volcanic Risk Solutions, School of Agriculture and Environment, Massey University,

7 Private Bag 11 222, 4414 Palmerston North, New Zealand; g.f.zellmer@massey.ac.nz,

8 r.brahm@massey.ac.nz

$9 \quad{ }^{2}$ Geological Survey of Japan, Advanced Institute of Science and Technology Tsukuba Central

10 7, 1-1-1 Higashi, Tsukuba, Ibaraki 305-8567, Japan; a.tomiya@aist.go.jp

11 3Institut des Sciences de la Terre d'Orléans, UMR 7327, CNRS/INSU-Université d'Orléans-

12 BRGM, 1A rue de la Férollerie, 45071 Orléans, France; s_jego@hotmail.com

13 *Corresponding author: d.a.coulthard@massey.ac.nz, phone: +64 211681669

14 Keywords: Experimental Petrology, Internally Heated Pressure Vessel, Magma Ascent,

15 Timescales, Crystal-Melt Disequilibrium, 
20 Boninites are rare high magnesium andesites that often contain trace chromites. These

21 chromites precipitate from primitive boninitic melts and are thought to be carried to the surface in melts that continue to crystallize a significant volume of silicate minerals. Such magmatic differentiation drives primitive chromite out of equilibrium with the residual melt with respect to both divalent and trivalent cation proportions. Diffusion then operates to alter primitive chromite toward a composition in equilibrium with residual melt. To simulate this process, we have performed internally heated pressure vessel experiments, providing insights into the processes of chromite-melt re-equilibration through time. While Fe-Mg exchange at magmatic temperatures equilibrates the tetrahedrally coordinated divalent cations in chromite in less than 6 hours, equilibration of trivalent cations in octahedral coordination with residual melts is slower. Our experimental results show that chromite $\mathrm{Al}$ concentrations are ubiquitously lower, and $\mathrm{Fe}^{2+} / \mathrm{Fe}^{3+}$ values are ubiquitously higher than modelled equilibrium values, indicating that there was insufficient time for significant $\mathrm{Al}$ and $\mathrm{Fe}^{3+}$ replacement of Cr. Similar observations can be made for natural chromite compositions in the extrusive sequence of the Troodos ophiolite (Cyprus). Based on a simple model of diffusive equilibration, we estimate that microphenocrystic chromites up to $60 \mu \mathrm{m}$ in diameter take between 60 days and c. 170 years to equilibrate under conditions analogous to the physiochemical state of melt immediately prior to eruption. For the Troodos ophiolite extrusive sequence, this implies that mafic magmas are erupted less than $c .170$ years after extraction from the mantle for disequilibrium textures and compositions to be preserved.

\section{INTRODUCTION}

41 Boninites are rare high magnesium andesites that are produced by the melting of highly

42 depleted mantle (harzburgite) under shallow and hydrous conditions (Pearce and Reagan, 2019). The paucity of this rock type in the geologic record may be attributed to the exotic 
nature of these petrogenetic conditions and/or the tendency of boninites to erupt in places

with a low preservation potential (e.g. forearc regions, Stern and Bloomer, 1992).

Nevertheless, boninites are generated in several tectonic settings including intraoceanic arcs (Meijer, 1980), intracontinental arcs (Tatsumi, 2006), back-arc basins (Falloon et al., 1992), and oceanic plateaus (Golowin et al., 2017). Additionally, several boninites have been found in ophiolite terranes (e.g. Bédard, 1999; Cameron, 1985; Dilek and Thy, 2009; Ishikawa et al., 2002; Meffre et al., 1996), though the tectonic settings of some ophiolites are topics of rigorous debate (cf. Gass, 1968; Metcalf and Shervais, 2008; Miyashiro, 1973; Moores et al., 2000; Pearce and Robinson, 2010; Regelous et al., 2014; Woelki et al., 2020; Woelki et al., 2018).

A cogenetic relationship between boninitic melt and podiform chromitite deposits found in some ophiolitic mantle sections has been hypothesized (Arai, 1997; Arai and Yurimoto, 1994, 1995; Rollinson, 2008; Rollinson et al., 2018; Zhou and Robinson, 1997; Zhou et al., 1994). With regard to podiform chromitite formation, it has been suggested that primitive hydrous melts react with depleted mantle, become silica-enriched via the incongruent melting of orthopyroxene (implying olivine crystallization), and crystallize a large volume of highCr\# chromite due to change in the number of available melt octahedral sites (Edwards et al., 2000). Separately, mechanisms of chromitite formation have been experimentally explored assuming immiscibility between melt-melt or melt-fluid components (Ballhaus, 1998; Matveev and Ballhaus, 2002). Initial immiscibility has been observed in other experimental studies that focused on the formation of boninitic melts via the same petrogenetic mechanism (i.e. incongruent melting, Fisk, 1986), and the boninitic composition of melts are preserved in equilibrium experiments that simulate melt-peridotite reactions (Mitchell and Grove, 2016). It is noteworthy that one experiment (C608) of Mitchell and Grove (2016) not only produced boninite melt in equilibrium with a dunite residual mantle mineral assemblage, but that the 
composition of the residual mineral assemblage overlaps with the most depleted end of the

olivine-spinel mantle array in compositional space (Arai, 1994). Ultimately, few studies have explicitly attempted to reconcile the links between boninite magma genesis, chromitite formation, and/or, more generally, chromite crystallization (Arai, 1997; Arai and Yurimoto, 1994, 1995; Rollinson, 2008; Rollinson et al., 2018; Zhou et al., 1994; Zhou et al., 1996).

If boninitic melts are generated during concomitant olivine and chromite precipitation as described above, then the appearance of high-Cr\# chromite (and forsteritic olivine) in boninites may be due to their removal from a mantle domain rather than crystallization from extracted melts in the crustal domain, where chromite has not been observed to crystallize under experimental conditions analogous to those that are realistic for primitive melt differentiation (e.g. pressures $>1$ bar, Umino and Kushiro, 1989).

It is important to specify the full implications of this model of boninite + chromitite petrogenesis, namely that boninite and chromitite appear to be linked by a cogenetic relationship based on observations of each in ophiolitic assemblages, that the underlying relationship is essentially a reactive transport process that occurs in the shallow subarc mantle, and that information on such processes may be inferred by detailed studies of chromite-melt or chromite-olivine-melt geochemistry; the systematics of which are preserved to different degrees in natural volcanic and plutonic suites (e.g. Kamenetsky et al., 2001). Further, if chromites are plucked from the melt-mantle petrogenetic system, then their melt inclusions (e.g. Kamenetsky et al., 2002; Umino et al., 2018; Umino et al., 2015) may give valuable information regarding the nature of magma genesis in the reactive transport regime.

In the present study, we conducted a series of high-pressure (c. 2 kbar) experiments to create systems wherein high silica boninite crystallized over brief time periods in the presence of stable chromite. The data presented here demonstrate that chromite is little affected by 
crystallization processes over short timescales unless unrealistically oxidizing conditions are imposed. Silicate mineral assemblages form via equilibrium crystallization in hydrous melts without significantly altering chromite compositions save for $\mathrm{Mg}-\mathrm{Fe}$ exchange when buffered near the nickel-nickel oxide (NNO) buffer. We propose that the systems represented by these experiments may be regarded as approximations of what occurs in natural chromite-bearing primary melts during their crustal differentiation (Scowen et al., 1991). Similar observations on partial chromite-melt equilibration in natural samples from the Troodos ophiolite (Cyprus) allow a coarse quantification of the extraction time for the mafic magmas of the extrusive suite, but more detailed diffusion chronometry on the chemical zonation patterns of natural chromites will be required to provide tight constraints.

\section{MATERIALS AND EXPERIMENTAL METHODS}

104 Crystallization experiments were performed using internally heated pressure vessels (IHPVs) at the Institut des Sciences de la Terre d'Orléans (ISTO), Université d'Orléans, France, as well as at the Geological Survey of Japan (GSJ) in Tsukuba, Japan. Additional sample

107 preparation took place at ISTO and at the Japan Agency for Marine-Earth Science and 108 Technology (JAMSTEC) in Yokosuka, Japan.

\subsection{Starting materials}

110 Table 1 provides major element data for the starting materials as well as the bulk composition

111 of the mixture used for the experiments. Analyses of the starting materials are given

112 alongside sample data in the supplemental Tables S1 and S2. A fragment of high-Si boninite

113 taken via dredging from the Mariana forearc (sample YK0612 974-R6, Reagan et al., 2010)

114 was chosen as a suitable starting material based on observed chromite phenocrysts and

115 microphenocrysts in thin section, which indicated chromite stability. The fragment was

116 powdered and fluxed to form glass, which was analysed during our routine spectrometric 
analysis (BO-G, Table S1) and re-powdered for sample loading. Chromite seeds sourced

118 from the mantle section of the Troodos Ophiolite were added to glass powders with the intent

119 of fostering further growth of chromite from boninitic melts. These seeds are unzoned and are

120 homogeneous (avg. $\mathrm{Mg} \#=62, \mathrm{Cr} /\left[\mathrm{Al}+\mathrm{Cr}+\mathrm{Fe}^{3+}\right]=70$ ). Two sample mixtures were made by

121 mixing powdered glass with one size fraction of chromite (either $>160 \mu \mathrm{m}$ or $<32 \mu \mathrm{m}$ in size), and each starting mixture contained $2 \%$ added chromite (by mass). The size of the seeds added to powdered glass were initially varied in order to test if seed size affects the resultant modal mineralogy of the sample.

125 Nominally pure platinum capsules were used as sample containers. Sample mixtures were

126 first loaded and then hydrated with heavy water $\left({ }^{2} \mathrm{H}_{2} \mathrm{O}\right)$ using a microsyringe before the 127 capsules were welded shut. Each capsule contained c. $1 \mathrm{wt} \%{ }^{2} \mathrm{H}_{2} \mathrm{O}$ prior to welding (Table 2).

$128{ }^{2} \mathrm{H}_{2} \mathrm{O}$ was used instead of ${ }^{1} \mathrm{H}_{2} \mathrm{O}$ to allow future analysis of water using secondary ion mass spectrometry, with this substitution enabling easy distinction between added water and background hydrogen. The quality of the welds was checked by immersing each capsule in

131 hot oil. All capsules were adequately sealed (poor welds emit a bubble stream, indicating an 132 inadequate seal).

$133 \mathrm{NiO}+\mathrm{NiPd}$ redox sensors added to each experiment allowed for the hydrogen fugacity $\left(f \mathrm{H}_{2}\right)$

134 imposed by the IHPV pressure medium to be evaluated, as redox sensors accurately reflect the oxygen fugacity $\left(\mathrm{O}_{2}\right)$ imposed by the gas buffer (Pownceby and O'Neill, 1994; Taylor et al., 1992). These sensors were made by packing two pellets into inert $\mathrm{ZrO}_{2}$ powder within a

137 platinum capsule so that the pellets are not in contact with the capsule wall. One pellet was 138 made of $50 \% \mathrm{NiO}$ and $50 \% \mathrm{Ni}_{\mathrm{x}} \mathrm{Pd}_{1-\mathrm{x}}$ and the other was made of $50 \% \mathrm{NiO}$ and $50 \% \mathrm{Ni}_{\mathrm{y}} \mathrm{Pd}_{1-\mathrm{y}}$,

139 with $\mathrm{x}=0.5$ and $\mathrm{y}=0.85$. Deionized water was added until the capsule interior became 
140 visibly saturated. Then the capsule was welded shut. Welds were checked in the same way

141 for the sensors as they were for the sample capsules.

\section{$142 \quad 2.2 . \quad$ Experimental design}

143 The IHPVs used at ISTO and GSJ both employed molybdenum furnaces to perform the high

144 temperature experiments described here. Since the same amount of water was initialized in

145 each sample, by varying the temperature of the experiments between 1200,1150 , and $1100^{\circ} \mathrm{C}$,

146 variable degrees of crystallinity are achieved in each sample. This determines the

147 concentration of water in residual melts, as the crystallization of nominally anhydrous mafic

148 minerals enriches the melt volume in incompatible volatile elements. The experiments were

149 performed under isobaric conditions, which means the final variable to consider is the $f \mathrm{O}_{2}$ of

150 the system.

151 Target oxygen fugacities were $c$. 1-3 log units above the NNO buffer, which are analogous to

152 magmas generated in subduction zone settings (Brandon and Draper, 1996; Evans et al.,

153 2012; Kelley and Cottrell, 2009; Parkinson and Arculus, 1999). The oxidation states were

154 either left unbuffered or buffered by pressurizing the IHPV with an $\mathrm{Ar}-\mathrm{H}_{2}$ gas mixture

$155\left(\mathrm{pH}_{2}{ }^{\text {added }}\right.$, Table 2). Pt capsules are permeable to hydrogen, which diffuses through the

156 capsule wall to bond with oxygen in the melt so that reduction of the sample volume occurs

157 (Chou et al., 1978; Shaw, 1963). Since the volume of the pressure medium is much greater

158 than the volume of the sample capsule, the pressure medium is effectively an infinite

159 reservoir with respect to hydrogen. Thus, the effective concentration of hydrogen available to

160 each capsule during a given experiment, $f \mathrm{H}_{2}$, may be considered constant. Unbuffered

161 experiments cause the redox state of melts to approach a condition known as the intrinsic $f \mathrm{O}_{2}$

162 of the IHPV. The intrinsic $f \mathrm{O}_{2}$ of IHPV systems is highly oxidizing (NNO+2 to $\mathrm{NNO}+4$,

163 Scaillet et al., 1992; Taylor et al., 1992, see further discussion in Supplemental Text 1). 
164 The experiments described here each lasted less than 6 hours. The utility of short-period experiments is multifaceted. From a volcanological perspective, fast ascending magmas are extracted from their crustal domains and extruded onto the surface in as little as tens of

167 minutes (Lloyd et al., 2016) when melts are hot $\left(>1000^{\circ} \mathrm{C}\right)$ and volatile rich. Short timescales

168 of the order of hours to days have also been inferred for volatile poor arc magmas (Lormand

169 et al., 2020). In a rapidly ascending melt, a variety of concomitant processes may alter the

170 physiochemical state of the melt volume, including syn-eruptive mixing (e.g. Tomiya et al.,

171 2013; Wolf and Eichelberger, 1997), crystallization (e.g. Blundy and Cashman, 2005;

172 Cashman and Blundy, 2000), and whole-rock contamination (e.g. Mattioli et al., 2006). Such

173 processes, along with subtleties such as the inclusion of antecrystic minerals, produce

174 disequilibrium mineral assemblages that provide valuable insight into the latest stages of magmatism (Couch et al., 2001; La Spina et al., 2016; Ubide et al., 2014; Zellmer et al., 2016; Zellmer et al., 2014). Thus, for natural magmatic systems, brief durations on the order

177 of hours represent an end member in an ascent period context, and disequilibrium

178 characteristics may be useful if properly placed into a petrogenetic context. Given boninite

179 petrogenesis occurs at relatively shallow depths and generates hot and hydrous melts,

180 sometimes in extensional settings (Reagan et al., 2017), rapid ascent rates cannot be

181 precluded. Furthermore, since it is possible that chromites preserved in boninite matrices may

182 have been generated within the source regions of the melts, knowledge of how these minerals

183 react to changes in the physiochemical states of the melts (i.e. experimental observation) is

184 needed in order to assess and contextualize natural sample materials. These considerations

185 provide an incentive to perform experiments on brief timescales and to analyse

186 disequilibrium features. 
Analytical facilities at Victoria University of Wellington, Hokkaido University, Massey

University, and The University of Iowa were utilized to gather the data presented here.

190 Following removal of the sample holder from the IHPV, each capsule was weighed to assess

191 for mass loss during the experiment. The capsules were then mounted in epoxy and ground to

192 expose their interiors. Ni-Pd alloys recovered from each sensor capsule was separated from

193 powdered $\mathrm{ZrO}_{2}$ and mounted in epoxy. These sample materials were then polished for

194 imaging and microprobe analysis, using SiC lapwheels and diamond grit paste.

\subsection{Electron microbeam techniques}

196 Samples produced at ISTO were imaged using an FEI Quanta 200 Environmental scanning

197 electron microscope (SEM) at the Manawatu Microscopy and Imaging Centre (Massey

198 University). This SEM was also used to perform semi-quantitative analyses of calcic silicate

199 minerals using an attached EDAX energy dispersive spectroscope (EDS). Samples produced

200 at GSJ were imaged at the Creative Research Institute of Hokkaido University using a JEOL

201 JSM-7000F Field Emission SEM. An attached XMAX 150 EDS was used here to analyse the

202 capsule Pt walls in contact with sample melts in order to detect iron loss after each

203 experiment (Supplemental Text 2, Table S3). Quantification of Fe in Pt was achieved by

204 calibrating signal intensity to pure Co.

205 Electron probe microanalysis (EPMA) occurred at multiple laboratories: at Victoria

206 University of Wellington and The University of Iowa, JEOL JXA-8230 Superprobes were

207 used. Additional chromite analyses were performed at Hokkaido University on a JEOL JXA-

208 8800R. Glass analyses were performed using Na-migration mitigation techniques. In addition

209 to using diffuse beam conditions (spot sizes of 5-10 $\mu \mathrm{m}$ ), two Na acquisitions are totalled. If

210 analyses return low concentrations (determined using secondary standards), then sodium loss

211 may be corrected by either: removing the second acquisition (if $\mathrm{Na}$ is lost), removing either 
212 point (if either indicates loss), or back-calculating time-resolved intensity to correct for $\mathrm{Na}$

213 loss. No analyses reported here experienced significant sodium migration as indicated by

214 multiple analyses of both sample and standard materials.

215 Secondary standards provided by the Smithsonian Institution Department of Mineral Sciences

216 and/or the Max Planck Institute for Chemistry were included in all glass and mineral

217 analyses. Ni-Pd sensor compositions were quantified using metal standards by Astimex.

218 Repeat analyses of secondary standards provided a basis to assess the accuracy of data

219 gathered during EPMA (Tables S1-S2, and S4). The accuracies associated with glass analyses

220 have been determined to be within $1 \%$ for $\mathrm{SiO}_{2}, \mathrm{Al}_{2} \mathrm{O}_{3}, \mathrm{MgO}$, and $\mathrm{CaO}, 5 \%$ for $\mathrm{TiO}_{2}, \mathrm{FeO}$,

221 and $\mathrm{K}_{2} \mathrm{O}, 10 \%$ for $\mathrm{Na}_{2} \mathrm{O}$, and $20 \%$ for $\mathrm{MnO}$. For analyses of silicate minerals, $\mathrm{SiO}_{2}, \mathrm{MgO}$,

$222 \mathrm{CaO}$, and $\mathrm{Na}_{2} \mathrm{O}$ are accurate to within $1 \%$, while $\mathrm{FeO}, \mathrm{Cr}_{2} \mathrm{O}_{3}, \mathrm{MnO}$, and $\mathrm{Al}_{2} \mathrm{O}_{3}$ are better than

$2232 \%$. Chromite standardization was achieved using several mineral and oxide standards.

224 Replicate standard analyses demonstrated that all major elements given are accurate to within

$2255 \%$, while $\mathrm{MnO}$ is accurate to within $40 \%$. Secondary standard compositions are taken from

226 Jarosewich et al. (1980); Jochum et al. (2006); and Jochum et al. (2005).

227 To ensure analyses of pyroxene were of high quality, raw EPMA data were normalized prior

228 to formulae recalculation using the methods described by Putirka (2008). Analyses that

229 returned cation totals much greater than or less than 4 (on an $\mathrm{O}=6$ basis) were discarded. In

230 a similar manner, raw chromite analyses were recalculated to cation proportions per 4

231 oxygens. Recalculation of ferric iron proportions used the equation of Droop (1987). No

232 other multivalent cations (e.g. Mn, Cr) were considered.

\subsection{Determination of phase proportions}

234 In order to provide high-precision phase proportion data, a computationally inexpensive

235 machine learning tool enabled the analysis of backscattered electron (BSE) images and 
produced segmented images that we interpreted in terms of phase proportions using Adobe

237 Photoshop. Segmented images are images that have been petrographically interpreted using a

238 machine learning algorithm and are color-coded based on which phase each pixel represents

239 (Supplemental Text 3). The machine learning tool used is called Trainable Weka

240 Segmentation, and was developed by Arganda-Carreras et al. (2017). The algorithm requires

241 limited user input (5-8 user-defined groups of pixels) to "train" the computer-generated

242 classifier, which segments as many mineral phases as the user defines This tool produced the segmented images used to infer the phase proportions given in Table 2. The tool is provided as a plugin on the Fiji Is Just ImageJ (FIJI) platform (Schindelin et al., 2012). A minimum of

2455 training sessions were conducted for each analysis, and the data derived from each segmented image were averaged to produce the given proportions with the calculated standard deviation providing the precision of each phase classification. Images representative of the sample textures were used for segmentation. See Supplemental Text 3 for more information and an example of a segmented image.

\subsection{Determination of oxygen fugacities from the solid sensors}

Fugacity calculations were performed following the methodology of Scaillet et al. (1995).

Sensor compositions, $X \mathrm{Ni}(\mathrm{Ni} /[\mathrm{Ni}+\mathrm{Pd}]$ calculated using cation proportion), were determined following EPMA. Further discussion of fugacity, including the calculation methodology, is provided in the Supplemental Text 1.

\section{RESULTS}

256 Weighing the capsules after quench indicated that no mass was lost during any experiment.

257 Table 2 gives information on each sample including the mixture used, initial water

258 concentration, experimental conditions, resultant phase proportions inferred for each sample,

259 sensor compositions, and $f \mathrm{O}_{2}$ data. 
260 The capsule interiors of every sample except for Bon1200Ub were analysed via EDS in order

261 to assess the degree of iron loss from the melt to the Pt of the capsule wall. Line analyses

262 from the sample-wall contact into the capsule wall yielded no detectable iron c. $30 \mu \mathrm{m}$ from

263 the interface. Integrating concentration profiles demonstrates that iron loss in unbuffered

264 experiments is limited to $10 \%$ or lower (of bulk sample Fe), while buffered experiments lost

265 20-35\% Fe over experiment durations (Supplemental Text 2, Table S3). However, we will

266 demonstrate that none of our discussion topics have been significantly affected by iron loss.

\subsection{Petrographic observations}

268 Euhedral-subhedral orthopyroxene (opx) is abundant and is the only silicate phase present at $1200^{\circ} \mathrm{C}$ and $1150^{\circ} \mathrm{C}$ (Figure $\left.1 \mathrm{~A}\right)$. In BSE images, these crystals often have bright caps that

270 form at the apices of euhedral crystal forms (Figure 1B). At $1100^{\circ} \mathrm{C}$, a petrographically distinct trace silicate phase was observed along with abundant opx in Bon1100U (Figure 1C). Semi-quantitative EDS analyses of this phase demonstrate that this silicate is rich in $\mathrm{Ca}, \mathrm{Mg}$, and $\mathrm{Fe}$. If it is a pyroxene, it is likely augite $\left(c . \mathrm{Wo}_{31} \mathrm{En}_{57} \mathrm{Fs}_{12}\right)$. Chromite is stable in all boninitic samples, and BSE images of moderate-sized grains show that chromite mantles have become brighter than cores (Figure 1D), indicating that diffusive equilibration was interrupted by quenching in large grains. In general, all chromites appear as anhedral grains with sharp-subrounded corners. These are not indications of chromite growth, suggesting that all observed chromites are the original seeds added to each experiment. Likewise, there is no evidence of dissolution, which indicates that chromite was a stable phase for the full duration

280 of each experiment. This implies that our experiments only produced pyroxene crystallization 281 in the presence of stable chromite. 
282 A small number of micro-vesicles occur in all boninitic samples (e.g. Figure 1A). The

283 vesicles are spherical and show no indication of clustering. They appear randomly distributed

284 within the sample volume. No vapour films were observed along any of the capsule walls.

\subsection{Redox sensors and calculation of imposed $\mathrm{fO}_{2}$}

286 Average $X \mathrm{Ni}$ values were calculated for each sensor and used to infer sensor $\mathrm{fO}_{2}$ for each

287 experiment. For water undersaturated sample melts, $\mathrm{aH}_{2} \mathrm{O}$ must be modelled in order to

288 accurately calculate $f \mathrm{O}_{2}$. To this end, the activity model of Burnham (1979) was used in

289 conjunction with major element data and inferred melt water concentrations (Supplemental

290 Text 1) to model $\mathrm{aH}_{2} \mathrm{O}$. The uncertainties reported here for $f \mathrm{O}_{2}$ are similar to those reported

291 elsewhere for the solid sensor technique (Jégo et al., 2010; Scaillet et al., 1995). The

292 solubility model of Zhang et al. (2007) was used to calculate maximum water concentrations

293 in residual melts under the experimental conditions, which correspond to $c$. 5.3-5.4 wt\%.

294 According to these model constraints, boninitic melts did not reach saturation (Table 2), and

295 the ubiquitous presence of micro-vesicles (Figure 1A) is therefore not due to water saturation

296 (exsolution) but likely due to the inclusion of atmospheric gas in the sample capsules during

297 preparation.

298 Complexities associated with quench crystallization were observed in samples Bon1200Ua

299 Bon1200Ub, Bon1200Ba and Bon1200Bb and are discussed later. A principal effect of

300 quench crystallization is to raise $\mathrm{aH}_{2} \mathrm{O}$ in residual melts. Thus, for these high-T samples, the

301 reported $f \mathrm{O}_{2}$ data are considered maxima.

\subsection{Compositional Data}


Representative compositional data are given in Table 3. Full sample datasets for each phase, including secondary standard analyses, data compiled from the literature, and model data, are given in Tables S1-S2 and S4. Literature data cited for comparison are provided in Table S5.

\subsubsection{Glass compositions}

307 Residual melts formed andesitic glasses, the compositions of which are given with other

308 experimental products in Table 3. These glasses are depleted in $\mathrm{FeO}, \mathrm{MnO}, \mathrm{MgO}$, and $\mathrm{Cr}_{2} \mathrm{O}_{3}$

309 relative to both the initial boninite glass as well as the bulk composition of the system

310 (Table 1). $\mathrm{SiO}_{2}, \mathrm{CaO}, \mathrm{Al}_{2} \mathrm{O}_{3}, \mathrm{Na}_{2} \mathrm{O}, \mathrm{K}_{2} \mathrm{O}$, and $\mathrm{TiO}_{2}$ are enriched in residual melt during every 311 experiment, which is consistent with extensive opx crystallization.

312 The two experiments conducted at high temperature (Bon1200U and Bon1200B) returned

313 four samples with glasses containing low $\mathrm{MgO}$ concentrations relative to those from

314 experiments conducted at $1150^{\circ} \mathrm{C}$. This is counterintuitive, because the crystallization of opx

315 at higher temperature should produce a lower proportion of minerals relative to lower

316 temperatures, and overall depletion of $\mathrm{MgO}$ and $\mathrm{FeO}$ relative to the initial glass composition

317 should be smaller. Additionally, glass compositions inferred for sample Bon1200Ua indicate

318 a high degree of heterogeneity beyond the limit of analytical uncertainty, consistent with

319 inefficient quenching producing local melt heterogeneity. These data, along with relatively

320 high melt $\mathrm{K}_{2} \mathrm{O}$ concentrations and the presence of abundant rim formation on opx grains

321 within these samples (Figure 1B) indicate that a significant degree of quench crystallization

322 has occurred in the high temperature experiments. These observations are absent from all

323 experiments conducted at $1150-1100^{\circ} \mathrm{C}$, which suggests that quenching was efficient in these

324 latter experiments and that no quench crystallization occurred. 
Opx formed under every temperature and redox condition imposed by the IHPV. In order to

confirm the identity of low-Ca pyroxenes as opx and not pigeonite, we calculated calcium

molar fractions for an opx-clinopyroxene (cpx) dividing line using equation 38 of Beattie et

al. (1991) with the experimental temperatures imposed within the IHPV as the single independent variable. All pyroxene data presented here fall below these model values, which confirms their identity as opx. Opx compositions are graphically illustrated in Figure 2.

Plotted alongside these data are data taken from other experiments conducted using boninitic bulk compositions (Tatsumi, 1981; Umino and Kushiro, 1989) and natural opx compositions sourced from boninitic rocks (Mariana trench, Bloomer and Hawkins, 1987; Troodos ophiolite, Cameron, 1985; and Chichijima, Umino, 1986; Yajima and Fujimaki, 2001).

Opx $\mathrm{Mg} \#$ (molar $\mathrm{Mg} /\left[\mathrm{Mg}+\mathrm{Fe}_{\text {Total }}\right]$ ) positively correlates with temperature, and under buffered redox conditions is lower than in unbuffered products (Figure 2). Differences in $\mathrm{MgO}$ and FeO concentrations observed in samples processed at $1200^{\circ} \mathrm{C}$ but different $f \mathrm{O}_{2}$ are on the order of $1-2 \mathrm{wt} \%$ for each element. Thus, lower $\mathrm{Mg \#}$ is associated both with lower temperature as well as lower $\mathrm{fO}_{2}$. Minor oxide components in opx include $\mathrm{CaO}, \mathrm{Na}_{2} \mathrm{O}, \mathrm{Cr}_{2} \mathrm{O}_{3}$, $\mathrm{MnO}, \mathrm{TiO}_{2}$, and $\mathrm{Al}_{2} \mathrm{O}_{3}$. The concentrations of each of these oxides are $<5 \mathrm{wt} \%$, with variation of some concentrations correlating with changes in the intensive parameters of the IHPV. Higher cation proportions of $\mathrm{Ca}, \mathrm{Al}$, and $\mathrm{Mn}$ are observed in samples synthesized under lower temperatures (Figure 2). $\mathrm{Cr}_{2} \mathrm{O}_{3}, \mathrm{Na}_{2} \mathrm{O}$ and $\mathrm{TiO}_{2}$ concentrations are extremely low in all pyroxenes, and potential variations in these oxides due to changes in temperature or redox condition are imperceptible when considering the detection limits for these elements.

347 The effects of imposing variable redox conditions on the melt-opx partitioning of $\mathrm{Ca}, \mathrm{Al}$, and

348 Mn cannot be discerned for a given temperature interval because, with regard to these

349 elements, the mean core compositions for all opx synthesized at a given temperature are not 350 observed to significantly change between high and low $f \mathrm{O}_{2}$. 
351 When natural and other experimental opx compositions are compared to the experimentally synthesized opx presented here, the majority of natural and experimental opx compositions are similar to opx synthesized at $1200^{\circ} \mathrm{C}$ and under buffered $f \mathrm{O}_{2}$ conditions in terms of their Mg\#. Mn proportions broadly overlap with products of high temperature crystallization, while $\mathrm{Al}$ and $\mathrm{Ca}$ cation proportions from the literature are, respectively, somewhat lower and higher than our experimental products.

\subsubsection{Chromite compositions}

Initial seed chromite fragments were analysed by EPMA in order to determine if the chromitite pod could be considered homogeneous. Representative data are given in Table 1 with other starting material compositions. A single analysis revealed minimal enrichment of $\mathrm{FeO}$ and $\mathrm{TiO}_{2}$ (Table S2). Because the level of enrichment is low and rarely observed, we consider the seed chromite to be homogeneous.

Experimental chromite compositions are chromium-rich, typically with $70<\mathrm{Cr} \#<81(\mathrm{Cr} \#=$ molar $\mathrm{Cr} /[\mathrm{Cr}+\mathrm{Al}]$, Table 3), and compositional data are illustrated in Figure 3. Priority was given to small seed chromites (c. 10-15 $\mu \mathrm{m}$ in diameter) that were able to be analysed without significant Si-contamination of the analysis volume from adjacent glass. This was because

367 the initial goal of adding seed chromite was to foster mineral growth from the boninitic

368 liquid. Since this likely did not occur, then the next best action was to analyse material that most likely equilibrated with residual melts by the end of each experiment. Two samples seeded with large chromite fragments (Bon1200Ua and Bon1200Ba) were observed to also contain several small anhedral chromite fragments distributed among the opx crystals

372 (possibly chromite powder contamination from the sieving process). Several of these were analysed in Bon1200Ua, but no analyses of chromite in Bon1200Ba were determined to be 
free of glass contamination based on high observed concentrations of $\mathrm{Si}, \mathrm{Ca}$, and, in some cases, Na. These data were rejected.

376 Compositions taken from the literature on boninite-hosted chromites sourced from the

377 Mariana trench wall (Bloomer and Hawkins, 1987), the Troodos ophiolite (Bailey et al., 378 1991; Cameron, 1985; Flower and Levine, 1987; MacLeod, 1988; Thy and Xenophontos, 379 1991), Guam (Reagan and Meijer, 1984), and Chichijima (Umino, 1986) are provided for 380 comparison. Note that the chromites from Thy and Xenophontos (1991) are olivine-hosted mineral inclusions.

In terms of trivalent cation proportions (i.e. $\mathrm{Fe}^{3+}, \mathrm{Al}$, and $\mathrm{Cr}$ ), $f \mathrm{O}_{2}$ buffered experiments produced chromites with compositions that did not significantly change from the initial seed composition (Figure 3A). Chromium is efficiently oxidized above NNO in iron-bearing melts (Hanson and Jones, 1998). Thus, all $\mathrm{Cr}$ in chromite is $\mathrm{Cr}^{3+}$. However, some of these chromites have bright mantles that clearly indicate Fe enrichment (e.g. Figure 1D). Under intrinsic $f \mathrm{O}_{2}$ conditions corresponding to $c$. 3.2-4.0 log units above the NNO buffer and at temperatures of $1200-1150^{\circ} \mathrm{C}$ (red and yellow diamonds on Fig. 3), significant amounts of $\mathrm{Fe}^{3+}$ were added to chromite, resulting in an enrichment of total $\mathrm{FeO}$ with concentrations $>20$ $\mathrm{wt} \%$. For these samples, their trend on Figure $3 \mathrm{~A}$ illustrates significant $\mathrm{Fe}^{3+}-\mathrm{Al}$ exchange between chromite and melt, as the trend of core compositions runs sub-parallel to lines of equal Cr proportion (which caused the observed increase in $\mathrm{Cr} \#$ for these chromites). Because this trend is linear and the samples do not cluster, it is likely that the $\mathrm{Fe}^{3+}-\mathrm{Al}$ exchange

394 reaction failed to reach equilibrium. It is noteworthy that chromite grains in sample

395 Bon1100U appear to have lost very little $\mathrm{Al}$ during the experiments, as $\mathrm{Al}_{2} \mathrm{O}_{3}$ concentrations are $\leq 1 \mathrm{wt} \%$ different from concentrations in the seed chromite, consistent with the observed invariance of their inferred $\mathrm{Fe}^{3+}$ contents. $\mathrm{TiO}_{2}$ was consistently low in all chromites, 
reaching a maximum value of $0.14 \mathrm{wt} \%$ under the lowest temperature setting (Bon1100U).

$\mathrm{NiO}$ concentrations were nearly constant throughout the dataset at c. $0.11 \mathrm{wt} \%$.

400 The literature data lie on a separate trend on Figure 3A that is sub-parallel to lines of constant

$401 \mathrm{Fe}^{3+}$ proportion. Of these data, chromite inclusions in olivine from the Kythreotis locality

402 (Troodos, Thy and Xenophontos, 1991) and matrix chromite from Guam appear to be the

403 most aluminous, while sample material from the Mariana Trench and Chichijima plot together near the extreme $\mathrm{Cr}$ end of the ternary diagram along with other Troodos chromites.

In fact, chromite compositions from Troodos boninites and tholeiites span a wide range on observed for the Kapilio locality (Cameron, 1985). The similarity between some of the chromites observed in Troodos boninites/tholeiites and the seed chromites from the plutonic chromitite is noted, as it was by Cameron (1985).

In Figure 3B, $\mathrm{Mg} \#$ (chromite $\mathrm{Mg} \#=\mathrm{Mg} /\left[\mathrm{Mg}+\mathrm{Fe}^{2+}\right]$ using molar proportions) is plotted

411 against $\mathrm{Fe}^{3+} /\left[\mathrm{Fe}^{3+}+\mathrm{Cr}+\mathrm{Al}\right]$ (also calculated using molar proportions) in order to visualize the

412 effects of iron enrichment in a compositional space that is more representative of the spinel

413 (sensu lato, hereafter s.l.) solid solution. Again, it is evident that buffered experiments

414 (squares) have the same $\mathrm{Fe}^{3+}$ proportion as seed chromite. However, it is apparent that some

$415{\mathrm{Mg}-\mathrm{Fe}^{2+}}^{2}$ exchange has occurred at $1150^{\circ} \mathrm{C}$, which represents the rim formation reaction

416 observed in BSE images (yellow square). Thus, in $f \mathrm{O}_{2}$ buffered experiments conducted at

$4171150^{\circ} \mathrm{C}, \mathrm{Fe}^{2+}$ has been added to chromite and $\mathrm{Mg}$ has been lost to the melt. For a given

418 temperature, $\mathrm{Mg} \#$ appears to decrease with $\mathrm{Fe}^{3+}$ incorporation. This is observed for samples

419 recovered from experiments Bon1200U and Bon1150U, which plot to higher $\mathrm{Fe}^{3+}$ relative to 420 products of buffered experiments. Interestingly, natural chromite compositions observed in 421 the Troodos ophiolite span a slightly greater range of $\mathrm{Mg} \#$ than the experimental products. 
Included in these data are additional olivine-hosted chromite inclusion data from Sobolev et al. (1993) and Golowin et al. (2017).

\section{DISCUSSION}

5.1. Assessment of divalent cation distribution and equilibrium state between chromiteopx-melt

427 Because the experiments described here did not produce any discernible chromite growth,

428 instead of discussing chromite crystallization, the following sections discuss the state and

429 kinetics of chromite equilibration. The physiochemical states imposed upon the boninite 430 system are analogous to a shallow-mid crust setting, and thus these experiments are ideally 431 suited to study the effects of chemical disequilibrium on compositional change as a function 432 of temperature and $f \mathrm{O}_{2}$ over brief timescales in this setting.

433 Based on textural evidence, it is apparent that large seed chromites in the samples presented

434 here failed to reach chemical equilibrium with their residual melts (Figure 1D). Since opx crystallization is the process that altered the major element composition of melts during each experiment, it is also the process that determines the extent to which chromite would have to interact with residual melt in order to reach an equilibrium state under the conditions imposed within the IHPV. Thus, it is important to qualify the relationship between opx and residual melt so that chromite-melt relationships can be confidently explored.

440 In order to test for opx-melt equilibrium, the methodology of Putirka (2008) was used.

441 Specifically, for a given sample, melt cation fractions were calculated ( $X_{\mathrm{d}}^{\text {liq }}$, Table S1) for 442 each glass analysis. From these values, $X_{\mathrm{Si}}{ }^{l i q}$ was used to calculate model equilibrium Fe-Mg exchange coefficients $\left(K_{D}\right.$, Table 4 , Figure $\left.4 A\right)$ using the following relationship given by

444 Putirka (2008): 


$$
\mathrm{K}_{\mathrm{D}}(\mathrm{Fe}-\mathrm{Mg})^{o p x-l i q}=0.4805-0.3733 X_{\mathrm{Si}}^{l i q}
$$

Equation 1

446 An uncertainty $(1 \sigma)$ of \pm 0.06 was attributed to these modelled $K_{D}$ values, which is an order

447 of magnitude higher than the $1 \sigma$ associated with the distribution of modelled $\mathrm{K}_{\mathrm{D}}$ values given

448 in Table 4 and is illustrated as areas on Figure 4A. Observed $\mathrm{K}_{\mathrm{D}}$ calculations employed molar

449 proportions for opx core analyses and average molar proportions for glass compositions.

450 Average $\mathrm{K}_{\mathrm{D}}$ values (including $2 \sigma$ error bars) for samples Bon1150U and Bon1150B plot

451 completely within their model areas, indicating that the opx sampled in these charges were in

452 equilibrium with their respective residual melts at the time of quenching. $K_{D}$ values

453 calculated for three opx cores in sample Bon1100U produce an average $\mathrm{K}_{\mathrm{D}}$ that is positioned

454 just outside of the model area. However, since the lower error bar stretches into the

455 uncertainty envelope as illustrated, it is reasonable to say that these crystals also equilibrated

456 with their residual melt. There are two negative effects of quench crystallization that

457 impacted $\mathrm{K}_{\mathrm{D}}$ calculations and prevented us from determining whether opx in samples

458 processed at $1200^{\circ} \mathrm{C}$ were able to reach equilibrium or not. The first is the effect of raising

$459 X_{\mathrm{Si}}^{l i q}$, which occurred as quench crystals removed $\mathrm{Mg}, \mathrm{Fe}$, and Ca from residual melts. This

460 lowers model $\mathrm{K}_{\mathrm{D}}$ values (Equation 1). The other effect is the removal of $\mathrm{Mg}$ and $\mathrm{Fe}$ from the

461 melt phase, which precluded realistic $K_{D}$ values from being observed (Figure 4A). Since opx-

462 melt $\mathrm{K}_{\mathrm{D}} \mathrm{S}$ indicate an equilibrium condition for experiments conducted at $1150-1100^{\circ} \mathrm{C}$, none

463 of the iron loss observed in these samples had an observable effect on the equilibrium

464 partitioning of Fe-Mg between opx and melt. This indicates that our equilibration

465 considerations are not significantly affected by this process.

466 In order to assess for chromite-opx equilibrium, the model of Liermann and Ganguly (2003)

467 was applied. This model was calibrated at higher pressures than imposed in our experiments.

468 However, because changes between partial molar volumes (of end-member compositions at 
the standard state) associated with the $\mathrm{Fe}^{2+}-\mathrm{Mg}$ exchange reaction between chromite and opx

470

471

472

473

474

475

476

477

478

479

480

481

482

483

484

485

486

487

488

489

490

491

492 appear to exhibit ideal mixing behaviour and because both $\mathrm{Fe}^{2+}$ and $\mathrm{Mg}$ endmembers exhibit similar and predictable pressure dependencies, Liermann and Ganguly (2003) assumed a pressure normalization scheme (their equation 5) to process their $\mathrm{K}_{\mathrm{D}}$ values and formulate a thermometer for opx-chromite pairs that may be applied under a wide range of pressure conditions. We have rearranged this thermometer (their equation 8) to predict chromite-opx $\mathrm{K}_{\mathrm{D}}\left(\mathrm{Fe}^{2+}-\mathrm{Mg}\right.$, Table 4$)$ at $2 \mathrm{kbar}(0.2 \mathrm{GPa})$ :

$$
\mathrm{K}_{\mathrm{D}}\left(\mathrm{Fe}^{2+}-\mathrm{Mg}\right)^{c h r m-o p x}=\exp \left[\frac{\mathrm{AT}(\mathrm{K})+\mathrm{B}+122 \mathrm{P}(\mathrm{GPa})-\mathrm{C} X_{\mathrm{A} I}^{o p x}+\mathrm{DY}_{\mathrm{Cr}}^{\text {chrm }}}{\mathrm{T}(\mathrm{K})}\right] \quad \text { Equation } 2
$$

This $\mathrm{K}_{\mathrm{D}}$ equation utilizes opx $\mathrm{Al}$ molar proportion $\left(X_{\mathrm{Al}}^{\text {opx }}\right)$, chromite $\mathrm{Cr} /\left[\mathrm{Cr}+\mathrm{Al}+\mathrm{Fe}^{3+}\right]$ $\left(Y_{\mathrm{Cr}}{ }^{c h r m}\right)$, and constants derived for $\mathrm{Al}-\mathrm{Fe}^{3+}$ system correction using the charge balance method: $\mathrm{A}=-0.351 \pm 0.102, \mathrm{~B}=1217 \pm 120, \mathrm{C}=1863$, and $\mathrm{D}=2345 \pm 188$ (Table 4 of Liermann and Ganguly, 2003). Uncertainties associated with the model $\mathrm{K}_{\mathrm{D}} \mathrm{s}$ were calculated to be \pm 0.157 (i.e. better than $\pm 7 \%, 2 \sigma$ relative) based on propagating the uncertainties provided for coefficients A, B, and D. Assuming the compositional parameter for opx does not significantly change, and since Cr proportions for the synthetic chromites are not observed to change significantly between any of the samples (Figure 3A), this equation predicts the equilibrium state of chromite-opx with regard to $\mathrm{Fe}^{2+}-\mathrm{Mg}$ exchange for each experimental condition at the time of quenching (Figure $4 \mathrm{~B}$, observed $\mathrm{K}_{\mathrm{D}}$ values were calculated using molar proportions with chromite $X_{\mathrm{FeO}}$ multiplied by molar $\mathrm{Fe}^{2+} / \Sigma \mathrm{Fe}$ inferred from stoichiometry).

As illustrated on Figure 4B, the $\mathrm{Fe}^{2+}-\mathrm{Mg}$ subcomposition of chromite (given as $\mathrm{Mg} \#$ in Figure 3B) in several samples has equilibrated with the opx-melt subsystem over the brief timescale of these experiments. The relatively large seed shown in Figure 1D has a rim that is c. 8-10 $\mu \mathrm{m}$ wide. Because our analyses prioritized small chromites that were $c .10-15 \mu \mathrm{m}$ in 
493 diameter, we consider it likely that EPMA sampled chromite that completely equilibrated

494 with respect to $\mathrm{Fe}^{2+}-\mathrm{Mg}$ through diffusion.

495 Thus, since a self-consistent determination of equilibrium has been established using

496 empirical relationships, then the $\mathrm{Fe}^{2+}-\mathrm{Mg}$ data provided here describe the equilibrium

497 condition of the melt + opx + chromite system under high temperature and $\mathrm{fO}_{2}$ conditions

498 analogous to those in sub-arc crust. Interestingly, significant degrees of iron loss should raise

499 the $\mathrm{Mg} \#$ of the sample bulk composition even when the ratio of $\mathrm{Fe}^{2+}$ to $\mathrm{Fe}^{3+}$ in melt is

500 maintained by hydration (Supplemental Text 2). This effect should be observable in product

501 opx compositions, as higher melt Mg\# should result in higher opx Mg\#. Since this is not

502 observed (Figure 2, Table 3), then the observed iron loss (in the case of Bon $1150 \mathrm{~B}, 20 \%$ bulk

$503 \mathrm{Fe}$ ) does not significantly affect the equilibrium distribution of $\mathrm{Fe}^{2+}-\mathrm{Mg}$ under our

504 experimental conditions.

505 5.2. Assessing chromite-melt equilibrium based on model equilibrium trivalent cation 506 proportions

507 Since $\mathrm{Fe}^{2+}-\mathrm{Mg}$ has now been accounted for, it is prudent to also examine the equilibrium state

508 of the trivalent cations in chromite. To this end, multiple modelling methods were integrated

509 to predict equilibrium chromite compositions (with respect to trivalent cation proportions).

510 Our method modelled system compositional data using the alphaMELTS front end (Smith

511 and Asimow, 2005) and the MELTS thermodynamic model (Ghiorso and Sack, 1995) with

512 Rhyolite-MELTS system corrections enabled (Gualda et al., 2012). Nested modelling utilized

513 SPINMELT-2.0 (Nikolaev et al., 2018a, b), which calculated an alternative stable chromite

514 composition for each intermediate MELTS step. These models are likely to bookend actual

515 trivalent cation proportions in spinel (s.l.) compositional space (see Davis and Cottrell, 2018;

516 Nikolaev et al., 2018a, for information and discussion on how individual models behave 
when predicting chromite compositions). A detailed description of the modelling methodology is included in Supplemental Text 4. SPINMELT-2.0 cannot make sense of MELTS-modelled liquid compositions at $\mathrm{NNO}+3$ because the liquid composition at this condition lies outside of the calibration range for the SPINMELT-2.0 algorithm. Thus, SPINMELT-2.0 data are not available under highly oxidizing conditions.

Figure 5 illustrates the relationship between MELTS and SPINMELT-2.0 models and the difference between modelled compositions and the synthetic chromites produced in our experiments. Alternative models were created to observe the effect of $30 \%$ iron loss on the system (empty symbols, Figure 5). It appears that under highly oxidizing conditions and $1150-1200^{\circ} \mathrm{C}$, experimental chromite $\mathrm{Fe}^{3+} /\left[\mathrm{Fe}^{3+}+\mathrm{Cr}+\mathrm{Al}\right]$ values approach values that are attained at $\mathrm{NNO}+2$ in the MELTS models. Still, given the distance on the ternary diagram between modelled chromite compositions and our experimental data, none of the experimental chromites are in equilibrium based on observed trivalent cation proportions.

This includes model data that were generated under conditions where iron loss was accounted for. The principal effect of iron loss is to reduce the proportion of iron in equilibrium chromite. The trend to high $\mathrm{Fe}^{3+}$ concentrations observed for the oxidized samples illustrated in Figures $3 \mathrm{~A}$ and 5 are likely to represent a segment of a diffusion trend in ternary space. The concept of diffusion in this compositional space is explored below. Since the volume of chromite in the charges is invariant (i.e. no resorption or crystallization has been observed), then the process by which chromite equilibrates can exclusively be attributed to diffusion.

Differences between MELTS and SPINMELT-2.0 output data are surprisingly large but may

538 be attributed to both our modelling strategy (Supplemental Text 4) as well as inherent limitations of the model platforms. Models in the MELTS family tend to overpredict spinel

540 (s.l.) $\mathrm{Fe}^{3+}$ proportion and underpredict $\mathrm{Cr}$ proportion (Davis and Cottrell, 2018; Nikolaev et 
al., 2018a), and the creators of SPINMELT-2.0 claim that their model reproduces several petrologically important chemical aspects of chromite chemistry to better than $20 \%(\mathrm{Cr} / \mathrm{Al}$ and $\mathrm{Mg} / \mathrm{Fe}^{2+}$, Nikolaev et al., 2018a). What MELTS does describe accurately is Fe-Al

544 exchange within the system during melt evolution and thus likely provides a best fit topology

545 in compositional space (Davis and Cottrell, 2018). Because of these observations, we

546 reiterate that our modelling method likely bookends equilibrium chromite compositions;

547 keeping in mind that multiple experiments were performed beyond the calibration range of SPINMELT-2.0.

549 In the case where $\mathrm{Fe}^{2+}$ in chromite is in equilibrium with the co-existing melt/silicate mineral 550 assemblage, the interdiffusion of trivalent cations should occur in chromite with $\mathrm{Fe}^{2+} / \mathrm{Fe}^{3+}$ 551 higher than that in coexisting melt, as melt $\mathrm{Fe}^{2+} / \mathrm{Fe}^{3+}$ should always be higher than spinel

$552 \mathrm{Fe}^{2+} / \mathrm{Fe}^{3+}$ (Maurel and Maurel, 1982). Using equation 7 of Kress and Carmichael (1991), model melt $\mathrm{Fe}^{2+} / \mathrm{Fe}^{3+}$ values were generated (Table S1) using glass compositions and the intensive parameters imposed by the IHPV to show that most if not all experimental chromites must incorporate more $\mathrm{Fe}^{3+}$ before reaching an equilibrium $\mathrm{Fe}^{2+} / \mathrm{Fe}^{3+}$ threshold

556 (Figure 6). That is, in order to reach an equilibrium condition, the observed $\mathrm{Fe}^{2+} / \mathrm{Fe}^{3+}$ in 557 chromite must incorporate more $\mathrm{Fe}^{3+}$ so that their ratio values fall below the grey lines on 558 Figure 6. The exception is sample Bon $1200 \mathrm{Bb}$, the chromite $\mathrm{Fe}^{2+} / \mathrm{Fe}^{3+}$ values of which are distributed (mostly) beneath the modelled melt $\mathrm{Fe}^{2+} / \mathrm{Fe}^{3+}$ value.

560 The diffusion of major cations within spinel (s.l., e.g. Figure 19 of Van Orman and Crispin, $5612010)$ are ranked by order of decreasing diffusivity $\left(\log \mathrm{D}, \mathrm{m}^{2} / \mathrm{s}\right)$ at $1100^{\circ} \mathrm{C}\left(10^{4} / \mathrm{K}=c .7 .3\right)$ :

$562 \mathrm{Mg}-\mathrm{Al}$ (extrapolated, c. -13.5), Fe (self-diffusion, c. -16), Mg (self-diffusion, c. -16.5), and 563 Cr-Al (below x-axis, see below). Thus, $\mathrm{D}_{\mathrm{Cr}-\mathrm{Al}}$ is likely the limiting factor in chromite-melt 564 diffusive equilibration, though uncertainties associated with $\mathrm{D}_{\mathrm{Cr}-\mathrm{Al}}$ are reportedly large at high 
565 Cr\# (Suzuki et al., 2008) and $f \mathrm{O}_{2}$ affects $\mathrm{D}_{\mathrm{Fe}}$ (Vogt et al., 2015). As stated by Vogt et al.

566 (2015) this behaviour is not well constrained under high-T and high-P conditions. Our results

567 corroborate this inference. Since spinel (s.l.) is an isometric mineral, the given diffusivities do

568 not vary with crystallographic orientation, which is convenient for the purpose of textural

569 analysis (Supplemental Text 5).

570 As demonstrated in Figure 3A, when buffered at NNO $+0.4,+1$ and +2.5 , chromite compositions did not significantly change from the original seed composition with respect to trivalent cation proportion. Only change in $\mathrm{Mg} \#$ is observed for these chromites (Figure 3B). Significant $\mathrm{Fe}^{3+}$ incorporation was only observed in unbuffered samples at $\mathrm{T}>1100^{\circ} \mathrm{C}$ and occurred at the expense of $\mathrm{Al}$, since trivalent cation proportions for these samples are distributed along lines of equal Cr proportion (Figure 3A). Thus, Al counter-diffusion facilitated $\mathrm{Fe}^{3+}$ incorporation in chromite under highly oxidizing conditions at $1150-1200^{\circ} \mathrm{C}$; although it is unlikely these minerals completely equilibrated during the experiments (Figure 5).

The Fe-Mg and Fe-Al exchange reactions have also been observed in natural samples that are allowed to equilibrate over decadal timescales (Scowen et al., 1991). Importantly, the observations of Scowen et al. (1991) confirm the rank of the diffusivities outlined above and establish that even though $\mathrm{Cr}$ is the most sluggish element to diffuse, eventually $\mathrm{Cr}$ diffusion does occur in natural settings to equilibrate chromite following Fe-Al interdiffusion.

584 Based on our observations, we hypothesize that $\mathrm{Fe}^{3+}-\mathrm{Al}$ interdiffusion operates principally as 585 a function of $\mathrm{O}_{2}$ to equilibrate chromite $\mathrm{Fe}^{2+} / \mathrm{Fe}^{3+}$ (after equilibration of chromite $\mathrm{Mg} \#$ ) on a 586 shorter timescale than is required to equilibrate $\mathrm{Cr}$ in the system. This scenario of diffusive 587 re-equilibration may be conceptualized within a multi-step chemical reaction (Figure 7). The first step concerns $\mathrm{Fe}^{2+}-\mathrm{Mg}$ exchange between chromite and melt. This is the only reaction 
observed in samples processed under buffered $\mathrm{fO}_{2}$ (and in sample Bon1100U), and since the

observed changes in chromite composition are more complex under higher $f \mathrm{O}_{2}$ conditions, we magnetite component $\left(\mathrm{FeFe}_{2} \mathrm{O}_{4}\right)$ is added to the starting chromite composition. This exchange

594 is facilitated by the counter-diffusion and exchange of $\mathrm{Mg}$ and $\mathrm{Al}$, and the spinel (sensu stricto, hereafter s.s.) component thus diminishes (see Table S2 for modelled end-member component compositions). With reaction 1 , the chromite composition approaches a tie line between $\mathrm{Fe}(\mathrm{Al}, \mathrm{Cr})_{2} \mathrm{O}_{4}$ and $\mathrm{Mg}(\mathrm{Fe}, \mathrm{Cr})_{2} \mathrm{O}_{4}$ in the compositional space of the spinel (s.l.) prism (dashed grey line in Figure 7A). Importantly, the chromite compositional trend will not approach the Cr-magnetite solid solution in the prism space but a spinel (s.l.) composition intermediate between Cr-magnetite and the $\mathrm{Mg}(\mathrm{Fe}, \mathrm{Cr})_{2} \mathrm{O}_{4}$ solid solution, as spinel (s.l.) $\mathrm{Mg}$ concentration is only being diluted by reaction 1 (i.e. $\mathrm{Mg}$ is rearranged within the chromite matrix with some flux across the crystal-melt boundary). In order to equilibrate $\mathrm{Cr}$ proportion, which is expected to decrease under all imposed experimental conditions

604 (Figure 5), compositions should evolve along lines of equal $\mathrm{Fe}^{3+} / \mathrm{Al}$ (dashed grey line in Figure 7B; reaction 2) in the isothermal state as $\mathrm{Cr}$ is lost to the melt phase. An added component with higher $\mathrm{Fe}^{2+} / \mathrm{Mg}$ is required because $\mathrm{Mg} \#$ in chromite was not observed to increase in any experiment (Figure 3B) and because this is necessary for chromite to equilibrate with the silicate mineral assemblage (Figure 4B).

The difference in diffusivities between mineral species provides an interesting constraint on

610 the origin of the polymineralic microlite assemblages described here. In particular, $\mathrm{Fe}-\mathrm{Mg}$

611 interdiffusion in opx occurs more slowly ( $\log \mathrm{D}=-19.5$ at QFM and high T, Klügel, 2001)

612 than interdiffusion of any of the major cations in chromite. If, in natural samples, it is found 613 that microlitic silicates like opx are in equilibrium with residual melts and matrix chromites 
are not, then the likely explanation for this observation is that the microlitic silicate formed

615 from the melt it is in (i.e. an equilibrium crystallization process). Crystallization of ferrous

616 phases is one of several oxidizing mechanisms in arc magmatic systems (see Cottrell et al.,

617 2020). This process provides an impetus for diffusive re-equilibration of chromite to begin,

618 and the grounds for oxyspeedometric analysis of the chromite-melt subsystem in a diffusion

619 chronometric context. Chromite crystals sampled from Chichijima (Umino, 1986), the

620 Troodos ophiolite (Bailey et al., 1991), and Guam (Reagan and Meijer, 1984) exhibit

621 chemical zonation consistent with pre-eruptive oxidation, as chromite rim-mantle zone

622 analyses return more ferric compositions than analyses of their cores. Such features are

623 unique to the pre-eruptive regime but may be confused with compositional trends that are

624 attributable to chemical weathering. Thus, it is important to discern here oxidation of

625 chromite that occurs in this scenario and oxidation that occurs post-eruption (i.e. chemical

626 weathering or metamorphism of chromite). In the literature on the zoned chromites described

627 above, there is no mention of textures consistent with porous-chromite oxidation (Gervilla et

628 al., 2019; Hodel et al., 2020). The volcanic rocks sampled by the studies cited above were

629 observed to be fresh with little to no evidence of alteration, which is not consistent with a

630 weathering environment capable of significantly modifying chromite compositions in either

631 hydrothermal (Hodel et al., 2020) or metamorphic (Gervilla et al., 2019) regimes. Instead,

632 since the chromite $\mathrm{FeO}$ and $\mathrm{Al}_{2} \mathrm{O}_{3}$ concentrations are observed to increase from core to rim

633 (which is a geochemical signature of magmatic oxidation in our model, i.e. reaction 2 of

634 Figure 7), we maintain that these zonation patterns are of magmatic rather than secondary

635 origin. With this in mind, the next sections assess natural chromite and glass compositions

636 recovered from the extrusive suite of the Troodos ophiolite in a similar manner as our

637 experimental products, and data available from the literature are used to constrain ascent rates

638 for these lavas. 
640 Mafic Troodos glass compositions were taken from the literature for the following localities:

641 the Kalavassos Mine (eastern end of the Limassol Forest Complex), Margi (northern part of

642 the extrusive sequence), and Kapilio (western end of the Limassol Forest Complex). All data

643 were taken from Woelki et al. (2020) with an additional two glass analyses from Golowin et

644 al. (2017) for the Kalavassos Mine locality. The studies cited used laser ablation inductively

645 coupled plasma mass spectrometry to quantify minor-trace concentrations of $\mathrm{Cr}$ for these

646 samples. Data on mineral compositions for these locations are sparse. However, multiple

647 compositions were found and taken from Cameron (1985), Bailey et al. (1991), Flower and

648 Levine (1987), and MacLeod (1988). Here, we assess these data to determine if the

649 aforementioned minerals and melts were in equilibrium at the time of eruption. Chromite data

650 were found neither for the Akaki River Canyon section nor for the Arakapas Fault Belt

651 though Ohnenstetter et al. (1990) performed several analyses, no data are provided in the

652 source. Thus, even though these locations have been widely studied, we are currently unable

653 to assess for chromite-melt equilibrium for these parts of the extrusive sequence.

654 SPINMELT-2.0 was used to model equilibrium chromite compositions in a similar way as in

655 the experimental scenario discussed above. Physiochemical variables were set to approximate

656 eruption conditions with pressure set to $0.5 \mathrm{kbar}$, which corresponds to a water depth of 5000

657 meters (inferred eruption condition, Woelki et al., 2020), and the $f \mathrm{O}_{2}$ of the system was set to

$658 \mathrm{QFM}+0.25$ (c. NNO-0.5), $\mathrm{QFM}+0.75$ (c. NNO), and QFM+1.25 (c. NNO+0.5). This range

659 compares well with the natural range of $f \mathrm{O}_{2}$ for the Troodos magmas; crystallization of

660 olivine + chromite occurred at fugacities slightly above QFM+0.25 (Golowin et al., 2017);

661 and glasses recovered from a Troodos "upper pillow lava" (Rautenschlein et al., 1985) have

$662 \mathrm{Fe}^{2+} / \mathrm{Fe}^{3+}$ (recalculated to molar ratios) that return $f \mathrm{O}_{2}$ values $\geq \mathrm{QFM}+1.35(\mathrm{NNO}+0.6)$ using 
a pressure of $0.5 \mathrm{kbar}$, a temperature of $1130^{\circ} \mathrm{C}$ (upper limit of eruption temperature given by

664 Golowin et al., 2017), a rearranged equation 7 from Kress and Carmichael (1991), and the

665 fugacity conversions of Frost (1991), providing a reasonable estimate for the upper limit for 666 our fugacity setting.

667 SPINMELT-2.0 output was treated in a similar way as the experimental data (Supplemental

668 Text 4). When $f \mathrm{O}_{2}$ is provided, melt $\mathrm{Fe}^{2+} / \mathrm{Fe}^{3+}$ is calculated internally and used to model

669 chromite composition. Since temperature is not provided to the program, it must be predicted

670 by the algorithm to provide a chromite composition estimate for each input melt composition.

671 For these lavas, liquid temperatures have been inferred to vary between $c .1030-1130^{\circ} \mathrm{C}$

672 (Golowin et al., 2017). These temperatures are consistent with temperatures inferred from

673 viscosity models (Schouten and Kelemen, 2002) generated for lavas on the North side of the

674 extrusive sequence and with independent thermometry (inferred to provide a quantification of

675 closure temperature) performed by Dare et al. (2009) for the Kalavassos Mine locality.

676 SPINMELT-2.0 output was observed to lie within $25^{\circ} \mathrm{C}$ of this temperature range for a

677 majority of the glass samples (Table S6) for each $f \mathrm{O}_{2}$ condition. Thus, we inferred that our models faithfully replicated equilibrium conditions for chromite-melt at the time of eruption.

Figure 8 illustrates the relationships between modelled and observed chromite compositions

680 of the Troodos (cf. Figure 5). Sample glass recovered from the Kalavassos Mine produced one major cluster for each $f \mathrm{O}_{2}$ condition and one Al-rich glass sample displaced modelled

682 chromite compositions to higher $\mathrm{Al}$ and lower $\mathrm{Cr}$. All glass samples were determined to be

683 "tholeiitic" by Woelki et al. (2020). All of the matrix chromite compositions observed for this 684 locality are similar to olivine-hosted chromite inclusions observed in these same lavas

685 (Golowin et al., 2017). A single natural chromite composition is displaced to higher Al 686 compared with the others. However, according to our models, all of these chromite 
compositions are too $\mathrm{Cr}$-rich and require $\mathrm{Fe}^{3+}+\mathrm{Al}$ incorporation to be in equilibrium with residual melts.

Woelki et al. (2020) determined that the glass samples recovered from the Kapilio locality range from boninitic to tholeiitic in composition. The chromite data from this locality include

691 the most chromian spinel (s.l.) analysis from the Troodos sample suite (Cameron, 1985) and

692 three relatively simple (number of elements reported $=4$ ) analyses of chromite given by

693 Flower and Levine (1987). These compositions are also far from the modelled chromite 694 compositions. As with the samples from the Kalavassos Mine, $\mathrm{Fe}^{3+}+\mathrm{Al}$ incorporation is required for re-equilibration. If a tie line is drawn through the natural samples from the $\mathrm{Cr}$ apex, it would intersect the model array at the point where the data generated at QFM +0.75

697 touches the data generated at QFM+1.25.

698 Finally, chromites taken from the Margi locality exhibit a compositional trend that is similar

699 to that observed in the data from the Kapilio suite. Glasses taken from this locality produced

700 a high-Al and low-Al trend, which reflects a modest separation of the glass data into more and less differentiated populations, respectively. Chromite core analyses given by Bailey et al. (1991) lie in roughly the same area as those of the Kalavassos Mine. However, rim analyses reported in this study are displaced to higher $\mathrm{Fe}^{3+}$ concentrations with a single analysis reaching the $\mathrm{Fe}^{3+}$ proportion inferred for chromite in equilibrium with melt at $\mathrm{QFM}+0.75$. However, for this mineral rim, $\mathrm{Cr}-\mathrm{Al}$ interdiffusion must also occur to reach the Al concentration inferred to represent an equilibrium composition. Thus, we conclude that the chromites observed in the Troodos extrusive suite were not in equilibrium with their residual melt compositions at the time of eruption, but in multiple localities these minerals were likely in a state of active equilibration (via diffusion) at the time they were erupted. 
710 Regarding $\mathrm{Fe}^{2+}$, slowly cooled chromites lose $\mathrm{Mg}$ to coexisting ferromagnesian silicates

711 (Ozawa, 1984), while rapidly quenched mineral pairs preserve high-temperature

712 compositions (e.g. Scowen et al., 1991). Since the glasses sampled from the Troodos rapidly

713 quenched upon eruption (e.g. Robinson et al., 1983), chromite Mg\# may have been

714 preserved. By focusing on a single locality where glass, opx, and chromite data exist, we may

715 treat natural samples in the same way as the experimental products above and test for system

$716 \mathrm{Fe}^{2+}-\mathrm{Mg}$ equilibrium. To this end, we refocus on the Kapilio locality. Glass data from this site

717 (Woelki et al., 2020) were processed to predict $\mathrm{K}_{\mathrm{D}}(\mathrm{Fe}-\mathrm{Mg})^{\text {opx-liq }}$ values using equation 1.

718 Mineral data from this locality are from Flower and Levine (1987). In total, two opx and

719 three chromite compositions were used (their sample AM-4, Table 5). Unfortunately, there is

720 no way of determining if these materials come from the same outcrops as the glass, which is

721 why all glass data were used in modelling. Based on model physiochemical constraints

722 outlined above, the opx sampled by Flower and Levine (1987) is in equilibrium with residual

723 melts (within $1 \sigma$ of the mean model $\mathrm{K}_{\mathrm{D}}(\mathrm{Fe}-\mathrm{Mg})^{\text {opx-liq }}$ value). Using a median $Y_{\mathrm{Cr}}{ }^{\text {chrm }}$ for the

724 matrix chromites $(0.70)$, model $\mathrm{K}_{\mathrm{D}}(\mathrm{Fe}-\mathrm{Mg})^{\text {chrm-opx }}$ values (calculated using equation 2) are

725 observed to vary between $c .4 .68-4.96$ at $1130^{\circ} \mathrm{C}$ and $0.5 \mathrm{kbar}$ and $5.41-5.86$ at $1030^{\circ} \mathrm{C}$ and

$7260.5 \mathrm{kbar}$ (Table 5). Varying $Y_{\mathrm{Cr}}{ }^{\text {chrm }}$ by 0.1 (the actual variation observed among the sample

727 chromites) causes these model $\mathrm{K}_{\mathrm{D}}$ values to vary by \pm 0.07 (c. $\pm 3 \%$ ), which is roughly one

728 half of the magnitude of the uncertainty associated with the model parameters. Observed

$729 \mathrm{~K}_{\mathrm{D}}(\mathrm{Fe}-\mathrm{Mg})^{\text {chrm-opx }}$ values are found to vary between 4.8 and 7.3 depending on which

730 chromite-opx pair is used. Two of the three chromite grains are seen to be in equilibrium with

731 at least one of the opx grains based on these $K_{D}$ models. One other chromite grain in this

732 sample returned high observed $\mathrm{K}_{\mathrm{D}}$ values for both opx grains, reflecting low $\mathrm{MgO}$

733 concentrations. This chromite also has a low total EPMA composition (94.79) compared to

734 the other analyses (c. 98). Regardless, it is remarkable, given the dearth of mineral data 
735

736

737

738

739

740

741

742

743

744

745

746

747

748

749

750

751

752

753

754

755

756

757

758

759

available for the Troodos extrusive sequence, that any equilibrium condition could be established at all. These findings further the point that more mineral data should be gathered

from the Troodos ophiolite and other natural chromite-bearing rocks to assess for mineralmineral/mineral-melt equilibrium.

The effects of natural quench crystallization and syn-eruptive microlite growth on modelling equilibrium chromite composition also needs to be considered. Depending on the Fe-Mg ratio of the minerals that crystallize, $\mathrm{Fe}^{2+}$ may be enriched or depleted in the residual melt. Using equilibrium exchange coefficients (e.g. Putirka, 2008), the crystallization of ferromagnesian silicates like olivine and opx are expected to enrich melts in $\mathrm{FeO}$ relative to $\mathrm{MgO}$, and the differentiation of melt by these minerals should modestly enrich $\mathrm{Fe}^{3+}$ over $\mathrm{Fe}^{2+}$ (Birner et al., 2018; Kelley and Cottrell, 2012; O'Neill et al., 2018; Shorttle et al., 2015). Melt $\mathrm{Al}_{2} \mathrm{O}_{3}$ is expected to increase with the equilibrium crystallization of ferromagnesian silicates. Based on observations of the experimental products made at $1200^{\circ} \mathrm{C}$, melt $\mathrm{Al}_{2} \mathrm{O}_{3}$ concentrations were not significantly affected by quench crystallization (Table 3). Although this effect will depend on the volume of crystallization produced during quenching, which was not constrained, we do not expect minor degrees of quench crystallization to significantly affect melt $\mathrm{Al}_{2} \mathrm{O}_{3}$ unless an aluminous phase crystallizes. In some relatively differentiated Troodos lavas, plagioclase feldspar is observed (Flower and Levine, 1987; Schmincke et al., 1983). Feldspar crystallization is expected to reduce melt $\mathrm{Al}_{2} \mathrm{O}_{3}$ and thus modelled chromite $\mathrm{Al}_{2} \mathrm{O}_{3}$ concentrations, which would cause observed chromite compositions to appear closer to equilibrium. Instead, we propose that (i) the higher chromite Al concentrations predicted by our modelling (Figure 8) reflect $\mathrm{Al}_{2} \mathrm{O}_{3}$ enrichment in the magmas (and thus the absence of plagioclase in glasses sampled by Woelki et al., 2020) that comprise the Troodos extrusive sequence, which is consistent with the predominate silicate mineral assemblages observed therein; namely olivine, olivine + cpx, or olivine+opx + cpx (Flower and Levine, 1987; Malpas 
and Langdon, 1984; Schmincke et al., 1983), and that (ii) quench crystallization does not significantly affect these data. Since the most primitive glasses sampled by Woelki et al.

762 (2018) were observed to classify as boninite liquids, we infer that the most Cr-rich equilibrium chromite compositions in our models (Figure 8), which correspond to these relatively primitive melt compositions, represent chromite compositions that genuinely reflect the equilibrium composition of chromite in melts unaffected by quench/syn-eruptive crystallization.

\subsection{Estimation of maximum/minimum ascent time through diffusion modelling}

Since stable chromite was driven into chemical disequilibrium during magmatic proportions at the time of eruption, and equilibrated with co-existing silicate minerals with respect to Fe-Mg exchange (divalent cation proportion), magma ascent time may be estimated on the basis of disequilibrium/equilibrium between chromite and the equilibrium condition defined by the physiochemical state of the residual melts. Here, the maximum ascent time was modelled based on the lowest interdiffusivity for the chromite compositional system $\left(\mathrm{D}_{\mathrm{Cr}-\mathrm{Al}}\right)$, and minimum ascent time was modelled based on the highest interdiffusivity

$776\left(\mathrm{D}_{\mathrm{Fe}-\mathrm{Mg}}\right)$.

777 Based on chromite-melt behaviour modelled above and observed in the mafic lavas of the extrusive suite of the Troodos ophiolite, we estimated the maximum and minimum ascent times by calculating the time (t) it would take to equilibrate a hypothetical groundmass chromite microphenocryst [30-60 $\mu \mathrm{m}$ diameter with a composition similar to those of

781 primitive chromite microphenocryst cores and mineral inclusions from the Kalavassos Mine

782 locality (Figure 8, Golowin et al., 2017; Sobolev et al., 1993)] with residual melt under the 783 inferred eruptive conditions using the following relationship from Crank (1975): 


$$
\tau=\mathrm{Dt} / \mathrm{a}^{2} \quad \text { Equation } 3
$$

785

786

787

788

789

790

791

792

793

794

795

796

797

798

799

800

801

802

where $\mathrm{a}$ is the crystal radius, $\mathrm{t}$ is time, $\mathrm{\tau}$ is non-dimensional time, and $\mathrm{D}$ is the interdiffusion coefficient.

$\mathrm{D}_{\mathrm{Cr}-\mathrm{Al}}$, the interdiffusivity coefficient of $\mathrm{Cr}-\mathrm{Al}$ in chromite, is positively correlated with both temperature and Cr\# (Suzuki et al., 2008). For this reason, we calculated $\mathrm{D}_{\mathrm{Cr}-\mathrm{Al}}$ for chromite with $\mathrm{Cr} \#=80$ at $1030^{\circ} \mathrm{C}$ and $1130^{\circ} \mathrm{C}$ by extrapolating the relationships illustrated in Figures 5 and 10 of Suzuki et al. (2008) to low temperatures. In detail, we reproduced the Arrhenius plot of Suzuki et al. (2008) for chromite with $\mathrm{Cr} \#=80$ and fit linear equations to their diffusivity data to predict $\log \mathrm{D}_{\mathrm{Cr}-\mathrm{Al}}$ as a function of temperature (Supplemental Text 5). The following equation was recovered:

$$
\log \mathrm{D}_{\mathrm{Cr}-\mathrm{Al}}=-2.4199\left(\frac{10^{4}}{\mathrm{~T}(\mathrm{~K})}\right)+2.3902
$$

Equation 4

Using this equation, we estimate $\log \mathrm{D}_{\mathrm{Cr}-\mathrm{Al}}\left(\mathrm{cm}^{2} / \mathrm{s}\right)$ to be -16.2 at $1030^{\circ} \mathrm{C}$ and -14.9 at $1130^{\circ} \mathrm{C}$ (Table 6).

We elected to use self-diffusion coefficients from Liermann and Ganguly (2002) to estimate $\log \mathrm{D}_{\mathrm{Fe}-\mathrm{Mg}}$ at the same conditions as $\log \mathrm{D}_{\mathrm{Cr}-\mathrm{Al}}$. We also reproduced their Arrhenius plots for both Fe and Mg self-diffusion (Supplemental Text 5) and then used their equation 4 to calculate an interdiffusivity coefficient, $\log \mathrm{D}_{\mathrm{Fe}-\mathrm{Mg}}$. For this calculation, we used the following linear equations recovered from their Arrhenius plots:

$$
\log \mathrm{D}_{\mathrm{Fe}}=-1.0322\left(\frac{10^{4}}{\mathrm{~T}(\mathrm{~K})}\right)-4.7506 \quad \text { Equation } 5
$$

$$
\log D_{M g}=-1.0545\left(\frac{10^{4}}{\mathrm{~T}(\mathrm{~K})}\right)-4.7125 \quad \text { Equation } 6
$$


804 Using these equations and equation 4 of Liermann and Ganguly (2002), $\log \mathrm{D}_{\mathrm{Fe}-\mathrm{Mg}}$ was

805 calculated to be -12.7 at $1030^{\circ} \mathrm{C}$ and -12.2 at $1130^{\circ} \mathrm{C}$ (Table 6$)$.

806 With these D values, we calculated maximum ascent time using the simple equation for

807 diffusion in a sphere (equation 3) by assuming $\tau=0.04$ (i.e. insignificant change in core

808 composition) and minimum ascent time by assuming $\tau=0.4$ (i.e. complete re-equilibration,

809 Table 6). At $1030^{\circ} \mathrm{C}$, in order to preserve a matrix chromite core whose $\mathrm{Cr} \#=80$, a maximum

810 of c. 170 years can pass before the core of the chromite begins to to equilibrate, which means

811 that the mafic lavas of the Troodos ophiolite, once extracted from their mantle source,

812 crystallized their silicate cargo and erupted in less than c. 170 years. If $\mathrm{T}$ is raised to $1130^{\circ} \mathrm{C}$,

813 the maximum amount of time is reduced to 8 years. Since the interdiffusivity coefficient is

814 positively correlated with $\mathrm{Cr} \#$, if chromite has a lower $\mathrm{Cr} \#$ than 80 , then maximum ascent

815 time increases. In fact, when $\mathrm{Cr} \#$ approaches $0, \mathrm{D}_{\mathrm{Cr}-\mathrm{Al}}$ approaches values two orders of

816 magnitude lower than when $\mathrm{Cr} \#=80$ (Suzuki et al., 2008). Maximum ascent times would

817 increase accordingly. However, because the chromites of the Troodos presented here are

818 highly chromian, we expect our maximum ascent times to be within reason. We calculated

819 minimum ascent time (for the same hypothetical chromite grain) at $1030^{\circ} \mathrm{C}$ to be $c .220$ days.

820 At $1130^{\circ} \mathrm{C}$ this value is lowered to 60 days. These back-of-the-envelope calculations

821 demonstrate that it will be possible to constrain the ascent rate of boninitic magmas through

822 study of diffusion profiles in matrix chromite crystals that they carry, and this should be done

823 systematically in future research.

824 Overall, the melt temperature data cited as independent observations for the Troodos

825 extrusive suite are corroborative, but it is important to discuss these data because temperature

826 exerts strong control over diffusion. The three methods of temperature estimation are based

827 on geochemical modelling (Dare et al., 2009; Golowin et al., 2017; Schouten and Kelemen, 
828 2002). Golowin et al. (2017) used olivine-melt compositional data and the equilibrium

829 relationships given by Ford et al. (1983) and Almeev et al. (2007) to quantify minimum

830 crystallization temperatures, which they interpreted as eruption temperatures. Schouten and

831 Kelemen (2002) used the geothermometer of Sisson and Grove (1993) to estimate

832 temperature for their viscosity models. Finally, Dare et al. (2009) calculated temperature

833 using the olivine-spinel thermometer of Ballhaus et al. (1991) and inferred this temperature as

834 a closure temperature for chromite. Taken together, since the present discussion is focused on

835 the kinetics of chromite-melt re-equilibration at pre-eruptive conditions, the estimates of

836 Golowin et al. (2017) represent our preferred liquid temperatures because they are most likely

837 to constrain melt temperatures prior to significant syn-eruptive crystallization of microlitic

838 pyroxene. Granted, when significant pyroxene crystallization occurs, melt water

839 concentrations assumed by Golowin et al. (2017) for Troodos glasses (c. $3 \mathrm{wt} \%$ ) represent

840 maxima and their temperatures minima following the liquidus depression relationships given

841 by Almeev et al. (2007). Woelki et al. (2020) quantified water concentrations in boninite

842 glasses to be $1.7-2.7 \mathrm{wt} \%$, which is slightly below the value provided by Golowin et al.

843 (2017). This means our models may use temperatures that are slightly underestimated. The

844 consequence of this is that our model ascent rates may be minima under high-temperature

845 conditions and that ascent times for the Troodos extrusive sequence may be higher than

846 modelled here. The likelihood of lower liquid temperatures are low due to the high closure

847 temperature of $1100^{\circ} \mathrm{C}$ inferred by Dare et al. (2009).

848 Additional complexity is added when considering the effect of changing Cr\# during

849 oxidation. Since $\log \mathrm{D}_{\mathrm{Cr}-\mathrm{Al}}$ becomes lower as chromite loses $\mathrm{Cr}$ (Suzuki et al., 2008), since we

850 elected to regress data provided for the highest Cr\# chromites in the study of Suzuki et al.

851 (2008) in order to estimate maximum ascent rate, and since natural chromites have slightly 
less $\mathrm{Cr}$ (Table S5), our maximum ascent times may be underestimated. This is an additional knowledge gap that should be addressed with future experimental work.

854 Because primitive compositional characteristics of the oxide mineral cargo are retained in several chromite crystals in the matrices of lavas of the Troodos ophiolite extrusive sequence and because, in some cases, mineral textures relating to diffusive equilibration seem to be

857 preserved, we propose that chromites in such boninitic-tholeiitic lavas are products of either

858 (i) crystallization from primary magmas or the incongruent melting reaction that is known to 859 produce olivine + chromite in the shallow sub-arc mantle, or (ii) crystallization in complex

860 fluid-melt or melt-melt mixtures in the same part of the magmatic system. In either case,

861 chromite is likely precipitated prior to extensive pyroxene crystallization, as melt

862 fractionation by pyroxene tends to compromise chromite stability in some igneous systems

863 (e.g. layered mafic intrusions or ocean island basalts, Irvine, 1967; Roeder, 1994). Such

864 behaviour appears to be absent in boninites and tholeiites associated with ophiolitic terranes

865 such as the Troodos or the forearc regions of intra-oceanic arc systems (e.g. Whattam et al., 866 2020). In these rocks, matrix chromite appears with stable pyroxene minerals as euhedral-

867 subhedral mineral grains with no signs of resorption or breakdown. Thus, chromite is most 868 likely a primitive component of the boninite-tholeiite petrogenetic system that perseveres through differentiation in arc systems and likely records compositional traits that reflect the

870 full range of physiochemical states these magmas undergo prior to eruption (Figure 9).

871 In our petrogenetic model, synthesized in Figure 9, chromite forms in equilibrium with

872 primitive boninitic melt prior to the growth of many silicate minerals (Figure 9B) and has a 873 primitive composition characterized by high $\mathrm{Mg} \#$ and $\mathrm{Y}_{\mathrm{Cr}}$ (Stage 1). Once silicate minerals 874 nucleate (Figure 9C), chromite Mg\# will immediately begin to re-equilibrate, as this 
876 silicates grow, melt oxidation occurs, and $\mathrm{Fe}^{3+}-\mathrm{Al}$ exchange begins (Stage 3, Figure 9D).

877 Finally, $\mathrm{Cr}$ exchange begins to occur with $\mathrm{Fe}^{3+}$ and $\mathrm{Al}$ (such that chromite $\mathrm{Fe}^{3+} / \mathrm{Al}$ remains

878 constant, Figure 7B) and the volume of chromite at the edge of the grain reaches an

879 equilibrium state with melt prior to eruption (Stage 4). If this chromite grain is entrained in an

880 ascending melt that is quenched upon eruption, then the differential diffusivities of the major

881 trivalent cations in chromite can be interpreted in a chronometric context (Figure 9E). Careful

882 analysis of chromite should include a quantification of Fe-speciation (see EPMA

883 methodology of Davis and Cottrell, 2018) so that precise thermometry and fugacity

884 information can be inferred from natural samples.

\section{6. CONCLUSIONS}

1) The experiments presented here enabled us to infer the kinetic behaviour of chromite in boninitic melt. Pyroxene is a ubiquitous component of the experimentally synthesized boninites, and residual melts are andesitic in composition. Matrix glasses preserved in natural boninites (Coulthard Jr et al., 2021; Woelki et al., 2020) demonstrate that olivine \pm pyroxene crystallization commonly generates residual melts that are basaltic andesitic to andesitic in composition, similar to the products of these crystallization experiments.

2) The fact that these same natural glasses are enriched in $\mathrm{Fe}^{3+}$ upon eruption (Brounce et al., 2019; Rautenschlein et al., 1985) suggests that primitive boninitic melts (i) crystallize chromite under less oxidizing conditions than those characteristic of the pre-eruptive crustal column and within what are likely complex melt-fluid/melt-melt mixtures present in the sub-arc or back-arc mantle, (ii) crystallize olivine/pyroxene phenocrysts under magmatic conditions without significant chromite crystallization in the crust, and (iii) entrain most of their chromite crystal cargo prior to microlitic 
growth during ascent and eruption, to produce natural boninites and derived andesiticbasaltic andesitic glasses.

902

903

904

905

906

907

908

909

910

911

912

913

914

915

916

917

918

919

920

921

922

3) If chromite, including microlitic matrix chromite, were to crystallize from these residual liquids, then they would incorporate more $\mathrm{Fe}^{3+}$ and $\mathrm{Al}$ than observed, as shown by the natural samples taken from the extrusive sequence of the Troodos Ophiolite. Thus, most chromites are products of primitive melt crystallization in the crustal domain or of the incongruent melting of orthopyroxene in the mantle domain. When entrained in an evolving magma, melt oxidation perturbs the equilibrium chromite composition to higher $\mathrm{Fe}^{3+}$. If sufficiently oxidizing conditions are achieved, $\mathrm{Fe}^{3+}$ replaces $\mathrm{Al}$ efficiently such that $\mathrm{Fe}^{2+} / \mathrm{Fe}^{3+}+\mathrm{Fe}^{3+} / \mathrm{Al}$ chromite-melt equilibrium is approached. The disequilibrium textures and compositions preserved in some phenocrystic-microphenocrystic chromites should be examined closely to ascertain ascent rates using $\mathrm{Fe}^{3+}$ diffusivity.

4) In chromite, $\mathrm{Cr}-\mathrm{Al} / \mathrm{Fe}^{3+}$ equilibrium is achieved over much longer timescales. If considered the limiting factor of chromite-melt equilibration, natural microphenocrystic chromite observed in the extrusive suite of the Troodos ophiolite would equilibrate with residual melts in less than $c .170$ years. Diffusion may be much more rapid, and future work on the diffusive equilibration of both experimental and natural chromites should provide tighter constraints.

\section{ACKNOWLEDGEMENTS}

Thanks go to Mark K. Reagan for providing the natural samples for these experiments, to Michel Pichavant for providing a wealth of insight into interpreting experimental oxygen fugacity data, to Keith Putirka for useful dialogue on opx-melt equilibrium uncertainties, to Fred Davis for insight on chromite equilibria as well as modelling methods, and finally to 
924 Alexandre Corgne and an anonymous reviewer for their constructive criticism of this

925 manuscript. This research was funded by the Royal Society of New Zealand through the

926 Marsden Fund (grant MAU1704 to GFZ). 
928

929

930

931

932

933

934

935

936

937

938

939

940

941

942

943

944

945

946

947

948

949

950

951

952

953

954

955

956

957

958

959

960

961

962

963

Almeev, R.R., Holtz, F., Koepke, J.r., Parat, F. and Botcharnikov, R.E. (2007) The effect of $\mathrm{H}_{2} \mathrm{O}$ on olivine crystallization in MORB: Experimental calibration at $200 \mathrm{MPa}$. American Mineralogist 92, 670-674.

Arai, S. (1994) Characterization of spinel peridotites by olivine-spinel compositional relationships: Review and interpretation. Chemical Geology 113, 191-204.

Arai, S. (1997) Origin of podiform chromitites. Journal of Asian Earth Sciences 15, 303-310.

Arai, S. and Yurimoto, H. (1994) Podiform chromitites of the Tari-Misaka ultramafic complex, southwestern Japan, as mantle-melt interaction products. Economic Geology 89, $1279-1288$.

Arai, S. and Yurimoto, H. (1995) Possible sub-arc origin of podiform chromitites. Isl. Arc 4, 104-111.

Arganda-Carreras, I., Kaynig, V., Rueden, C., Eliceiri, K.W., Schindelin, J., Cardona, A. and Sebastian Seung, H. (2017) Trainable Weka Segmentation: a machine learning tool for microscopy pixel classification. Bioinformatics 33, 2424-2426.

Bailey, D.G., Langdon, G.S., Malpas, J. and Robinson, P.T. (1991) Ultramafic and related lavas from the Margi area, Troodos ophiolite, in: Gibson, I.L., Malpas, J., Robinson, P.T., Xenophontos, C. (Eds.), Cyprus Crustal Study Project: Initial Report, Holes Cy-1 and 1a. Geological Survey of Canada, pp. 187-202.

Ballhaus, C. (1998) Origin of podiform chromite deposits by magma mingling. Earth and Planetary Science Letters 156, 185-193.

Ballhaus, C., Berry, R.F. and Green, D.H. (1991) High pressure experimental calibration of the olivine-orthopyroxene-spinel oxygen geobarometer: implications for the oxidation state of the upper mantle. Contributions to Mineralogy and Petrology 107, 27-40.

Beattie, P., Ford, C. and Russell, D. (1991) Partition coefficients for olivine-melt and orthopyroxene-melt systems. Contributions to Mineralogy and Petrology 109, 212-224.

Bédard, J.H. (1999) Petrogenesis of Boninites from the Betts Cove Ophiolite, Newfoundland, Canada: Identification of Subducted Source Components. Journal of Petrology 40, 18531889.

Birner, S.K., Cottrell, E., Warren, J.M., Kelley, K.A. and Davis, F.A. (2018) Peridotites and basalts reveal broad congruence between two independent records of mantle $\mathrm{fO}_{2}$ despite local redox heterogeneity. Earth and Planetary Science Letters 494, 172-189.

Bloomer, S.H. and Hawkins, J.W. (1987) Petrology and geochemistry of boninite series volcanic rocks from the Mariana trench. Contributions to Mineralogy and Petrology 97, 361377.

Blundy, J. and Cashman, K. (2005) Rapid decompression-driven crystallization recorded by melt inclusions from Mount St. Helens volcano. Geology 33, 793-796. 
964 Brandon, A.D. and Draper, D.S. (1996) Constraints on the origin of the oxidation state of

965 mantle overlying subduction zones: An example from Simcoe, Washington, USA.

966 Geochimica et Cosmochimica Acta 60, 1739-1749.

967 Brounce, M., Reagan, M.K., Coulthard Jr., D.A., Kelley, K.A. and Cottrell, E. (2019) The

968 oxidation states of iron and volatile compositions of Expedition 352 glasses, Goldschmidt

969 2019, Barcelona, Spain.

970 Burnham, C.W. (1979) The importance of volatile constituents, in: Yoder, H.S., Jr. (Ed.), The

971 evolution of the igneous rocks. Princeton University Press, Princeton, New Jersey, pp. 439-

972482.

973 Cameron, W.E. (1985) Petrology and origin of primitive lavas from the Troodos ophiolite,

974 Cyprus. Contributions to Mineralogy and Petrology 89, 239-255.

975 Cashman, K. and Blundy, J. (2000) Degassing and crystallization of ascending andesite and

976 dacite. Philosophical Transactions of the Royal Society of London. Series A: Mathematical,

977 Physical and Engineering Sciences 358, 1487-1513.

978 Chou, I.M., Eugster, H.P., Berens, P. and Weare, J.H. (1978) Diffusion of hydrogen through

979 platinum membranes at high pressures and temperatures. Geochimica et Cosmochimica Acta

$980 \quad 42,281-288$.

981 Cottrell, E., Birner, S., Brounce, M., Davis, F.A., Waters, L.E. and Kelley, K.A. (2020)

982 Oxygen Fugacity Across Tectonic Settings, in: Neuville, D.R., Moretti, R. (Eds.), AGU

983 Geophysical Monograph Redox variables and mechanisms in magmatism and volcanism.

984 Wiley.

985 Couch, S., Sparks, R.S.J. and Carroll, M.R. (2001) Mineral disequilibrium in lavas explained 986 by convective self-mixing in open magma chambers. Nature 411, 1037-1039.

987 Coulthard Jr, D.A., Reagan, M.K., Shimizu, K., Bindeman, I.N., Brounce, M., Almeev, R.R., 988 Ryan, J., Chapman, T., Shervais, J. and Pearce, J.A. (2021) Magma Source Evolution

989 Following Subduction Initiation: Evidence From the Element Concentrations, Stable Isotope

990 Ratios, and Water Contents of Volcanic Glasses From the Bonin Forearc (IODP Expedition

991 352). Geochemistry, Geophysics, Geosystems 22, doi: 10.1029/2020GC009054.

992 Crank, J. (1975) The Mathematics of Diffusion. Oxford University Press, London.

993 Dare, S.A.S., Pearce, J.A., McDonald, I. and Styles, M.T. (2009) Tectonic discrimination of 994 peridotites using $\mathrm{fO}_{2}-\mathrm{Cr} \#$ and $\mathrm{Ga}-\mathrm{Ti}-\mathrm{Fe}^{\mathrm{III}}$ systematics in chrome-spinel. Chemical Geology $995261,199-216$.

996 Davis, F.A. and Cottrell, E. (2018) Experimental investigation of basalt and peridotite

997 oxybarometers: Implications for spinel thermodynamic models and $\mathrm{Fe}^{3+}$ compatibility during 998 generation of upper mantle melts. American Mineralogist 103, 1056-1067.

999 Dilek, Y. and Thy, P. (2009) Island arc tholeiite to boninitic melt evolution of the Cretaceous 1000 Kizildag (Turkey) ophiolite: Model for multi-stage early arc-forearc magmatism in Tethyan 1001 subduction factories. Lithos 113, 68-87. 
1002 Droop, G.T.R. (1987) A general equation for estimating $\mathrm{Fe}^{3+}$ concentrations in

1003 ferromagnesian silicates and oxides from microprobe analyses, using stoichiometric criteria.

1004 Mineralogical Magazine 51, 431-435.

1005 Edwards, S.J., Pearce, J.A. and Freeman, J. (2000) New insights concerning the influence of 1006 water during the formation of podiform chromitite. Geological Society of America Special 1007 Papers 349, 139-148.

1008 Evans, K.A., Elburg, M.A. and Kamenetsky, V.S. (2012) Oxidation state of subarc mantle. 1009 Geology 40, 783-786.

1010 Falloon, T.J., Malahoff, A., Zonenshaina, L.P. and Bogdanova, Y. (1992) Petrology and geochemistry of back-arc basin basalts from Lau Basin spreading ridges at $15^{\circ}, 18^{\circ}$ and $19^{\circ} \mathrm{S}$. Mineralogy and Petrology 47, 1-35.

1013 Ferracutti, G.R., Gargiulo, M.F., Ganuza, M.L., Bjerg, E.A. and Castro, S.M. (2015)

1014 Determination of the spinel group end-members based on electron microprobe analyses.

1015 Mineralogy and Petrology 109, 153-160.

1016 Fisk, M.R. (1986) Basalt magma interaction with harzburgite and the formation of high1017 magnesium andesites. Geophysical Research Letters 13, 467-470.

1018 Flower, M.F.J. and Levine, H.M. (1987) Petrogenesis of a tholeiite-boninite sequence from 1019 Ayios Mamas, Troodos ophiolite: evidence for splitting of a volcanic arc? Contributions to 1020 Mineralogy and Petrology 97, 509-524.

1021 Ford, C., Russell, D., Craven, J. and Fisk, M. (1983) Olivine-liquid equilibria: temperature, 1022 pressure and composition dependence of the crystal/liquid cation partition coefficients for $1023 \mathrm{Mg}, \mathrm{Fe}^{2+}, \mathrm{Ca}$ and Mn. Journal of Petrology 24, 256-266.

1024 Frost, B.R. (1991) Introduction to oxygen fugacity and its petrologic importance. Reviews in 1025 Mineralogy and Geochemistry 25, 1-9.

1026 Gass, I.G. (1968) Is the Troodos Massif of Cyprus a Fragment of Mesozoic Ocean Floor? 1027 Nature 220, 39-42.

1028 Gervilla, F., Asta, M.P., Fanlo, 1., Grolimund, D., Ferreira-Sánchez, D., Samson, V.A., 1029 Hunziker, D., Colas, V., González-Jiménez, J.M., Kerestedjian, T.N. and Sergeeva, I. (2019) 1030 Diffusion pathways of $\mathrm{Fe}^{2+}$ and $\mathrm{Fe}^{3+}$ during the formation of ferrian chromite: a $\mu$ XANES 1031 study. Contributions to Mineralogy and Petrology 174, 65.

1032 Ghiorso, M.S. and Sack, R.O. (1995) Chemical mass transfer in magmatic processes IV. A revised and internally consistent thermodynamic model for the interpolation and extrapolation of liquid-solid equilibria in magmatic systems at elevated temperatures and pressures. Contributions to Mineralogy and Petrology 119, 197-212.

1036 Golowin, R., Portnyagin, M., Hoernle, K., Sobolev, A., Kuzmin, D. and Werner, R. (2017) 1037 The role and conditions of second-stage mantle melting in the generation of low-Ti tholeiites 1038 and boninites: the case of the Manihiki Plateau and the Troodos ophiolite. Contributions to 1039 Mineralogy and Petrology 172, 104. 
1040 Gualda, G.A., Ghiorso, M.S., Lemons, R.V. and Carley, T.L. (2012) Rhyolite-MELTS: a 1041 modified calibration of MELTS optimized for silica-rich, fluid-bearing magmatic systems. 1042 Journal of Petrology 53, 875-890.

1043 Hanson, B. and Jones, J.H. (1998) The systematics of $\mathrm{Cr}^{3+}$ and $\mathrm{Cr}^{2+}$ partitioning between 1044 olivine and liquid in the presence of spinel. American Mineralogist 83, 669-684.

1045 Hodel, F., Macouin, M., Trindade, R.I.F., Araujo, J.F.D.F., Respaud, M., Meunier, J.F., 1046 Cassayre, L., Rousse, S., Drigo, L. and Schorne-Pinto, J. (2020) Magnetic Properties of 1047 Ferritchromite and Cr-Magnetite and Monitoring of Cr-Spinels Alteration in Ultramafic and 1048 Mafic Rocks. Geochemistry, Geophysics, Geosystems 21, doi: 10.1029/2020GC009227.

1049 Irvine, T.N. (1967) Chromian spinel as a petrogenetic indicator. Part 2. Petrologic 1050 applications. Canadian Journal of Earth Sciences 4, 71-103.

Ishikawa, T., Nagaishi, K. and Umino, S. (2002) Boninitic volcanism in the Oman ophiolite: Implications for thermal condition during transition from spreading ridge to arc. Geology 30, 899-902.

1054 Jarosewich, E., Nelen, J.A. and Norberg, J.A. (1980) Reference Samples for Electron Microprobe Analysis*. Geostandards Newsletter 4, 43-47.

1056 Jégo, S., Pichavant, M. and Mavrogenes, J.A. (2010) Controls on gold solubility in arc magmas: An experimental study at $1000 \mathrm{C}$ and 4 kbar. Geochimica et Cosmochimica Acta $74,2165-2189$.

1059 Jochum, K.P., Stoll, B., Herwig, K., Willbold, M., Hofmann, A.W., Amini, M., Aarburg, S., 1060 Abouchami, W., Hellebrand, E., Mocek, B., Raczek, I., Stracke, A., Alard, O., Bouman, C., 1061 Becker, S., Dücking, M., Brätz, H., Klemd, R., de Bruin, D., Canil, D., Cornell, D., de Hoog, 1062 C.-J., Dalpé, C., Danyushevsky, L., Eisenhauer, A., Gao, Y., Snow, J.E., Groschopf, N., 1063 Günther, D., Latkoczy, C., Guillong, M., Hauri, E.H., Höfer, H.E., Lahaye, Y., Horz, K., 1064 Jacob, D.E., Kasemann, S.A., Kent, A.J.R., Ludwig, T., Zack, T., Mason, P.R.D., Meixner, 1065 A., Rosner, M., Misawa, K., Nash, B.P., Pfänder, J., Premo, W.R., Sun, W.D., Tiepolo, M., 1066 Vannucci, R., Vennemann, T., Wayne, D. and Woodhead, J.D. (2006) MPI-DING reference 1067 glasses for in situ microanalysis: New reference values for element concentrations and 1068 isotope ratios. Geochemistry, Geophysics, Geosystems 7.

1069 Jochum, K.P., Willbold, M., Raczek, I., Stoll, B. and Herwig, K. (2005) Chemical 1070 Characterisation of the USGS Reference Glasses GSA-1G, GSC-1G, GSD-1G, GSE-1G, 1071 BCR-2G, BHVO-2G and BIR-1G Using EPMA, ID-TIMS, ID-ICP-MS and LA-ICP-MS. 1072 Geostandards and Geoanalytical Research 29, 285-302.

1073 Kamenetsky, V.S., Crawford, A.J. and Meffre, S. (2001) Factors controlling chemistry of magmatic spinel: An empirical study of associated olivine, Cr-spinel and melt inclusions from primitive rocks. Journal of Petrology 42, 655-671.

1076 Kamenetsky, V.S., Sobolev, A.V., Eggins, S.M., Crawford, A.J. and Arculus, R.J. (2002) 1077 Olivine-enriched melt inclusions in chromites from low-Ca boninites, Cape Vogel, Papua 1078 New Guinea: evidence for ultramafic primary magma, refractory mantle source and enriched 1079 components. Chemical Geology 183, 287-303. 
Kelley, K.A. and Cottrell, E. (2009) Water and the Oxidation State of Subduction Zone Magmas. Science 325, 605-607.

1082 Kelley, K.A. and Cottrell, E. (2012) The influence of magmatic differentiation on the oxidation state of $\mathrm{Fe}$ in a basaltic arc magma. Earth and Planetary Science Letters 329-330, 109-121.

Klügel, A. (2001) Prolonged reactions between harzburgite xenoliths and silicaundersaturated melt: implications for dissolution and $\mathrm{Fe}-\mathrm{Mg}$ interdiffusion rates of orthopyroxene. Contributions to Mineralogy and Petrology 141, 1-14.

Kress, V.C. and Carmichael, I.S.E. (1991) The compressibility of silicate liquids containing $\mathrm{Fe}_{2} \mathrm{O}_{3}$ and the effect of composition, temperature, oxygen fugacity and pressure on their redox states. Contributions to Mineralogy and Petrology 108, 82-92.

La Spina, G., Burton, M., de' Michieli Vitturi, M. and Arzilli, F. (2016) Role of syn-eruptive plagioclase disequilibrium crystallization in basaltic magma ascent dynamics. Nature Communications 7, 13402.

1094 Liermann, H.-P. and Ganguly, J. (2002) Diffusion kinetics of $\mathrm{Fe}^{2+}$ and $\mathrm{Mg}$ in aluminous spinel: experimental determination and applications. Geochimica et Cosmochimica Acta 66, 2903-2913.

1097 Liermann, H.P. and Ganguly, J. (2003) $\mathrm{Fe}^{2+}-\mathrm{Mg}$ fractionation between orthopyroxene and 1098 spinel: experimental calibration in the system $\mathrm{FeO}-\mathrm{MgO}-\mathrm{Al}_{2} \mathrm{O}_{3}-\mathrm{Cr}_{2} \mathrm{O}_{3}-\mathrm{SiO}_{2}$, and applications. Contributions to Mineralogy and Petrology 145, 217-227.

1100 Lloyd, A.S., Ferriss, E., Ruprecht, P., Hauri, E.H., Jicha, B.R. and Plank, T. (2016) An 1101 Assessment of Clinopyroxene as a Recorder of Magmatic Water and Magma Ascent Rate. 1102 Journal of Petrology 57, 1865-1885.

1103 Lormand, C., Zellmer, G.F., Kilgour, G.N., Németh, K., Palmer, A.S., Sakamoto, N., 1104 Yurimoto, H., Kuritani, T., Iizuka, Y. and Moebis, A. (2020) Slow ascent of unusually hot 1105 intermediate magmas triggering Strombolian to sub-Plinian eruptions. Journal of Petrology.

1106 MacLeod, C.J. (1988) The tectonic evolution of the Eastern Limassol Forest Complex, 1107 Cyprus, Department of Earth Sciences. The Open University.

1108 Malpas, J. and Langdon, G. (1984) Petrology of the Upper Pillow Lava suite, Troodos 1109 ophiolite, Cyprus. Geological Society, London, Special Publications 13, 155-167.

1110 Mattioli, M., Renzulli, A., Menna, M. and Holm, P.M. (2006) Rapid ascent and 1111 contamination of magmas through the thick crust of the CVZ (Andes, Ollagüe region): 1112 Evidence from a nearly aphyric high-K andesite with skeletal olivines. Journal of 1113 Volcanology and Geothermal Research 158, 87-105.

1114 Matveev, S. and Ballhaus, C. (2002) Role of water in the origin of podiform chromitite 1115 deposits. Earth and Planetary Science Letters 203, 235-243.

1116 Maurel, C. and Maurel, P. (1982) Étude expérimentale de l'équilibre $\mathrm{Fe}^{2+}-\mathrm{Fe}^{3+}$ dans les 1117 spinelles chromifères et les liquides silicatés basiques coexistants, à $1 \mathrm{~atm}$. Comptes Rendus 1118 des Séances de l'Académie des Sciences 295. 
1119 Meffre, S., Aitchison, J.C. and Crawford, A.J. (1996) Geochemical evolution and tectonic

1120 significance of boninites and tholeiites from the Koh ophiolite, New Caledonia. Tectonics 15, $1121 \quad 67-83$.

1122 Meijer, A. (1980) Primitive arc volcanism and a boninite series: examples from western 1123 Pacific island arcs, in: Hayes, D.E. (Ed.), The Tectonic and Geologic Evolution of Southeast 1124 Asian Seas and Islands. American Geophysical Union, pp. 269-282.

1125 Metcalf, R.V. and Shervais, J.W. (2008) Suprasubduction-zone ophiolites: Is there really an 1126 ophiolite conundrum? Special Papers-Geological Society of America 438, 191.

1127 Mitchell, A.L. and Grove, T.L. (2016) Experiments on melt-rock reaction in the shallow 1128 mantle wedge. Contributions to Mineralogy and Petrology 171, 107.

1129 Miyashiro, A. (1973) The Troodos ophiolitic complex was probably formed in an island arc. 1130 Earth and Planetary Science Letters 19, 218-224.

1131 Moores, E.M., Kellogg, L.H. and Dilek, Y. (2000) Tethyan ophiolites, mantle convection, 1132 and tectonic" historical contingency": A resolution of the" ophiolite conundrum". Geological 1133 Society of America Special Papers 349, 3-12.

1134 Nikolaev, G.S., Ariskin, A.A. and Barmina, G.S. (2018a) SPINMELT-2.0: Simulation of spinel-melt equilibrium in basaltic systems under pressures up to $15 \mathrm{kbar}$ : I. model

1136

1137 Nikolaev, G.S., Ariskin, A.A. and Barmina, G.S. (2018b) SPINMELT-2.0: Simulation of 1138 Spinel-Melt Equilibrium in Basaltic Systems under Pressures up to 15 Kbar: II. Description 1139 of the Program Package, the Topology of the Cr-spinel-Melt Model System, and Petrological 1140 Implications. Geochemistry International 56, 125-135.

1141 O'Neill, H.S.C., Berry, A.J. and Mallmann, G. (2018) The oxidation state of iron in Mid1142 Ocean Ridge Basaltic (MORB) glasses: Implications for their petrogenesis and oxygen 1143 fugacities. Earth and Planetary Science Letters 504, 152-162.

1144 Ohnenstetter, M., Bechon, F. and Ohnenstetter, D. (1990) Geochemistry and mineralogy of 1145 lavas from the Arakapas Fault Belt, Cyprus: Consequences for magma chamber evolution. 1146 Mineralogy and Petrology 41, 105-124.

1147 Ozawa, K. (1984) Olivine-spinel geospeedometry: Analysis of diffusion-controlled Mg-Fe2+ 1148 exchange. Geochimica et Cosmochimica Acta 48, 2597-2611.

1149 Parkinson, I.J. and Arculus, R.J. (1999) The redox state of subduction zones: insights from 1150 arc-peridotites. Chemical Geology 160, 409-423.

1151 Pearce, J.A. and Reagan, M.K. (2019) Identification, classification, and interpretation of 1152 boninites from Anthropocene to Eoarchean using Si-Mg-Ti systematics. Geosphere 15, 100811531037.

1154 Pearce, J.A. and Robinson, P.T. (2010) The Troodos ophiolitic complex probably formed in a 1155 subduction initiation, slab edge setting. Gondwana Research 18, 60-81. 
1156 Pownceby, M.I. and O'Neill, H.S.C. (1994) Thermodynamic data from redox reactions at

1157 high temperatures. III. Activity-composition relations in Ni-Pd alloys from EMF

1158 measurements at $850-1250 \mathrm{~K}$, and calibration of the $\mathrm{NiO}+\mathrm{Ni}-\mathrm{Pd}$ assemblage as a redox

1159 sensor. Contributions to Mineralogy and Petrology 116, 327-339.

1160 Putirka, K.D. (2008) Thermometers and Barometers for Volcanic Systems. Reviews in

1161 Mineralogy and Geochemistry 69, 61-120.

1162 Rautenschlein, M., Jenner, G.A., Hertogen, J., Hofmann, A.W., Kerrich, R., Schmincke, H.U. 1163 and White, W.M. (1985) Isotopic and trace element composition of volcanic glasses from the 1164 Akaki Canyon, Cyprus: implications for the origin of the Troodos ophiolite. Earth and 1165 Planetary Science Letters 75, 369-383.

1166 Reagan, M.K., Ishizuka, O., Stern, R.J., Kelley, K.A., Ohara, Y., Blichert-Toft, J., Bloomer, 1167 S.H., Cash, J., Fryer, P., Hanan, B.B., Hickey-Vargas, R., Ishii, T., Kimura, J.-I., Peate, 1168 D.W., Rowe, M.C. and Woods, M. (2010) Fore-arc basalts and subduction initiation in the 1169 Izu-Bonin-Mariana system. Geochemistry Geophysics Geosystems 11.

1170 Reagan, M.K. and Meijer, A. (1984) Geology and geochemistry of early arc-volcanic rocks 1171 from Guam. GSA Bulletin 95, 701-713.

1172 Reagan, M.K., Pearce, J.A., Petronotis, K., Almeev, R.R., Avery, A.J., Carvallo, C., 1173 Chapman, T., Christeson, G.L., Ferré, E.C., Godard, M., Heaton, D.E., Kirchenbaur, M., 1174 Kurz, W., Kutterolf, S., Li, H., Li, Y., Michibayashi, K., Morgan, S., Nelson, W.R., Prytulak, 1175 J., Python, M., Robertson, A.H.F., Ryan, J.G., Sager, W.W., Sakuyama, T., Shervais, J.W., 1176 Shimizu, K. and Whattam, S.A. (2017) Subduction initiation and ophiolite crust: new insights 1177 from IODP drilling. Int. Geol. Rev. 59, 1439-1450.

1178 Regelous, M., Haase, K.M., Freund, S., Keith, M., Weinzierl, C.G., Beier, C., Brandl, P.A., 1179 Endres, T. and Schmidt, H. (2014) Formation of the Troodos Ophiolite at a triple junction: 1180 Evidence from trace elements in volcanic glass. Chemical Geology 386, 66-79.

1181 Robinson, P.T., Melson, W.G., O'Hearn, T. and Schmincke, H.-U. (1983) Volcanic glass 1182 compositions of the Troodos ophiolite, Cyprus. Geology 11, 400-404.

1183 Roeder, P.L. (1994) Chromite; from the fiery rain of chondrules to the Kilauea Iki lava lake. 1184 The Canadian Mineralogist 32, 729-746.

1185 Rollinson, H. (2008) The geochemistry of mantle chromitites from the northern part of the 1186 Oman ophiolite: inferred parental melt compositions. Contributions to Mineralogy and 1187 Petrology 156, 273-288.

1188 Rollinson, H., Mameri, L. and Barry, T. (2018) Polymineralic inclusions in mantle 1189 chromitites from the Oman ophiolite indicate a highly magnesian parental melt. Lithos 310$1190 \quad 311,381-391$.

1191 Scaillet, B., Pichavant, M. and Roux, J. (1995) Experimental crystallization of leucogranite

1193 Scaillet, B., Pichavant, M., Roux, J., Humbert, G. and Lefevre, A. (1992) Improvements of the Shaw membrane technique for measurement and control of $\mathrm{fH} 2$ at high temperatures and pressures. American Mineralogist 77, 647-655. 
1196 Schindelin, J., Arganda-Carreras, I., Frise, E., Kaynig, V., Longair, M., Pietzsch, T.,

1197 Preibisch, S., Rueden, C., Saalfeld, S. and Schmid, B. (2012) Fiji: an open-source platform

1198 for biological-image analysis. Nature methods 9, 676.

1199 Schmincke, H.-U., Rautenschlein, M., Robinson, P.T. and Mehegan, J.M. (1983) Troodos

1200 extrusive series of Cyprus: A comparison with oceanic crust. Geology 11, 405-409.

1201 Schouten, H. and Kelemen, P.B. (2002) Melt viscosity, temperature and transport processes,

1202 Troodos ophiolite, Cyprus. Earth and Planetary Science Letters 201, 337-352.

1203 Scowen, P.A.H., Roeder, P.L. and Helz, R.T. (1991) Reequilibration of chromite within

1204 Kilauea Iki lava lake, Hawaii. Contributions to Mineralogy and Petrology 107, 8-20.

1205 Shaw, H.R. (1963) Hydrogen-Water Vapor Mixtures: Control of Hydrothermal Atmospheres

1206 by Hydrogen Osmosis. Science 139, 1220-1222.

1207 Shorttle, O., Moussallam, Y., Hartley, M.E., Maclennan, J., Edmonds, M. and Murton, B.J.

1208 (2015) Fe-XANES analyses of Reykjanes Ridge basalts: Implications for oceanic crust's role

1209 in the solid Earth oxygen cycle. Earth and Planetary Science Letters 427, 272-285.

1210 Sisson, T.W. and Grove, T.L. (1993) Temperatures and $\mathrm{H}_{2} \mathrm{O}$ contents of low-MgO high-

1211 alumina basalts. Contributions to Mineralogy and Petrology 113, 167-184.

1212 Smith, P.M. and Asimow, P.D. (2005) Adiabat_1ph: A new public front-end to the MELTS,

1213 pMELTS, and pHMELTS models. Geochemistry, Geophysics, Geosystems 6.

1214 Sobolev, A., Portnyagin, M., Dmitriev, L., Tsameryan, O., Danyushevsky, L., Kononkova,

1215 N., Shimizu, N. and Robinson, P. (1993) Petrology of ultramafic lavas and associated rocks

1216 of the Troodos massif, Cyprus. Petrology 1, 331-361.

1217 Stern, R.J. and Bloomer, S.H. (1992) Subduction zone infancy: Examples from the Eocene

1218 Izu-Bonin-Mariana and Jurassic California arcs. GSA Bulletin 104, 1621-1636.

1219 Suzuki, A.M., Yasuda, A. and Ozawa, K. (2008) Cr and Al diffusion in chromite spinel:

1220 experimental determination and its implication for diffusion creep. Phys. Chem. Miner. 35,

1221433.

1222 Tatsumi, Y. (1981) Melting experiments on a high-magnesian andesite. Earth and Planetary 1223 Science Letters 54, 357-365.

1224 Tatsumi, Y. (2006) High-Mg Andesites in the Setouchi Volcanic Belt, Southwestern Japan: 1225 Analogy to Archean Magmatism and Continental Crust Formation? Annual Review of Earth 1226 and Planetary Sciences 34, 467-499.

1227 Taylor, J.R., Wall, V.J. and Pownceby, M.I. (1992) The calibration and application of 1228 accurate redox sensors. American Mineralogist 77, 284-295.

1229 Thy, P. and Xenophontos, C. (1991) Crystallization Orders and Phase Chemistry of Glassy 1230 Lavas from the Pillow Sequences, Troodos Ophiolite, Cyprus. Journal of Petrology 32, 4031231428. 
1232 Tomiya, A., Miyagi, I., Saito, G. and Geshi, N. (2013) Short time scales of magma-mixing

1233 processes prior to the 2011 eruption of Shinmoedake volcano, Kirishima volcanic group,

1234 Japan. Bulletin of Volcanology 75, 750.

1235 Ubide, T., Galé, C., Larrea, P., Arranz, E. and Lago, M. (2014) Antecrysts and their effect on 1236 rock compositions: The Cretaceous lamprophyre suite in the Catalonian Coastal Ranges (NE 1237 Spain). Lithos 206-207, 214-233.

1238 Umino, S. (1986) Magma mixing in boninite sequence of Chichijima, Bonin Islands. Journal 1239 of Volcanology and Geothermal Research 29, 125-157.

1240 Umino, S., Kanayama, K., Kitamura, K., Tamura, A., Ishizuka, O., Senda, R. and Arai, S.

1241 (2018) Did boninite originate from the heterogeneous mantle with recycled ancient slab? Isl.

1242 Arc 27, e12221.

1243 Umino, S., Kitamura, K., Kanayama, K., Tamura, A., Sakamoto, N., Ishizuka, O. and Arai, S. 1244 (2015) Thermal and chemical evolution of the subarc mantle revealed by spinel-hosted melt

1245 inclusions in boninite from the Ogasawara (Bonin) Archipelago, Japan. Geology 43, 151-154.

1246 Umino, S. and Kushiro, I. (1989) Experimental studies on boninite petrogenesis, in:

1247 Crawford, A.J. (Ed.), Boninites: And Related Rocks. Unwin and Hyman, London, pp. 89-

1248111.

1249 Van Orman, J.A. and Crispin, K.L. (2010) Diffusion in Oxides. Reviews in Mineralogy and 1250 Geochemistry 72, 757-825.

1251 Vogt, K., Dohmen, R. and Chakraborty, S. (2015) Fe-Mg diffusion in spinel: New

1252 experimental data and a point defect model $\uparrow$. American Mineralogist 100, 2112-2122.

1253 Whattam, S.A., Shervais, J.W., Reagan, M.K., Coulthard Jr., D.A., Pearce, J.A., Jones, P., 1254 Seo, J., Putirka, K., Chapman, T., Heaton, D., Li, H., Nelson, W.R., Shimizu, K. and Stern, 1255 R.J. (2020) Mineral compositions and thermobarometry of basalts and boninites recovered 1256 during IODP Expedition 352 to the Bonin forearc. American Mineralogist.

1257 Woelki, D., Michael, P., Regelous, M. and Haase, K. (2020) Enrichment of $\mathrm{H}_{2} \mathrm{O}$ and fluid1258 soluble trace elements in the Troodos Ophiolite: Evidence for a near-trench origin. Lithos 1259 356-357, 105299.

1260 Woelki, D., Regelous, M., Haase, K.M., Romer, R.H.W. and Beier, C. (2018) Petrogenesis of 1261 boninitic lavas from the Troodos Ophiolite, and comparison with Izu-Bonin-Mariana fore1262 arc crust. Earth and Planetary Science Letters 498, 203-214.

1263 Wolf, K.J. and Eichelberger, J.C. (1997) Syneruptive mixing, degassing, and crystallization 1264 at Redoubt Volcano, eruption of December, 1989 to May 1990. Journal of Volcanology and 1265 Geothermal Research 75, 19-37.

1266 Yajima, K. and Fujimaki, H. (2001) High-Ca and low-Ca boninites from Chichijima, Bonin 1267 (Ogasawara) archipelago. Japanese Magazine of Mineralogical and Petrological Sciences 30, $1268 \quad 217-236$.

1269 Zellmer, G.F., Sakamoto, N., Hwang, S.-L., Matsuda, N., Iizuka, Y., Moebis, A. and 1270 Yurimoto, H. (2016) Inferring the Effects of Compositional Boundary Layers on Crystal 
1271 Nucleation, Growth Textures, and Mineral Chemistry in Natural Volcanic Tephras through

1272 Submicron-Resolution Imaging. Frontiers in Earth Science 4.

1273 Zellmer, G.F., Sakamoto, N., Iizuka, Y., Miyoshi, M., Tamura, Y., Hsieh, H.-H. and

1274 Yurimoto, H. (2014) Crystal uptake into aphyric arc melts: insights from two-pyroxene 1275 pseudo-decompression paths, plagioclase hygrometry, and measurement of hydrogen in 1276 olivines from mafic volcanics of SW Japan. Geological Society, London, Special

1277 Publications 385, SP385. 383.

1278 Zhang, Y., Xu, Z., Zhu, M. and Wang, H. (2007) Silicate melt properties and volcanic 1279 eruptions. Reviews of Geophysics 45.

1280 Zhou, M.-F. and Robinson, P.T. (1997) Origin and tectonic environment of podiform 1281 chromite deposits. Economic Geology 92, 259-262.

1282 Zhou, M.F., Robinson, P.T. and Bai, W.J. (1994) Formation of podiform chromitites by 1283 melt/rock interaction in the upper mantle. Mineralium Deposita 29, 98-101.

1284 Zhou, M.F., Robinson, P.T., Malpas, J. and Li, Z. (1996) Podiform chromitites in the 1285 Luobusa ophiolite (Southern Tibet): Implications for melt-rock interaction and chromite 
1289 Figure 1: A) BSE image of Bon1150U. This image is representative of the "general" texture 1290 observed in the boninitic charges. This includes several examples of euhedral prismatic opx 1291 (dark mineral grains) and platy elongated opx (same colour) set in a relatively homogeneous 1292 glass with anhedral chromite (bright grains). The black orb-shaped parts are vapour bubbles.

1293 B) Close up of an opx cut parallel to the (010) plane exhibiting a ghost core (red ellipse). The 1294 core is likely related to crystallization occurring within the melt/glass phase before stable 1295 thermal conditions were achieved within the IHPV. The arrow points to bright caps that form 1296 at the apices of most if not all opx in this sample (from experiment Bon1200B). These caps

1297 are thought to have grown during quench. The glass adjacent to these minerals is darker,

1298 indicating the loss of iron to the quench-grown rim. C) Broad view of sample Bon1100U with 1299 calcic pyroxene highlighted (red ellipses). Several opx are aligned here, with their c-axes sub1300 perpendicular to the image plane. D) BSE image of chromite in Bon1150B after thresholding 1301 brightness and contrast to isolate and amplify Fe enrichment textures.

1302 Figure 2: Cation proportion $(\mathrm{O}=6)$ vs $\mathrm{Mg \#}$ (calculated using $\left.\mathrm{Fe}_{\mathrm{total}}\right)$ for opx core analyses.

1303 Literature data are taken from sources listed in the text. Point uncertainties are within the 1304 boundaries of the symbol.

1305 Figure 3: Chromite compositional data. A) A portion of a conventional ternary diagram 1306 illustrating the relative proportions of octahedrally coordinated trivalent cations after 1307 recalculation (dimensions of the ternary are illustrated on the inset). Literature data are taken

1308 from sources listed in the text. B) Diagram that illustrates Fe incorporation into both

1309 octahedral and tetrahedral sites using $\mathrm{Mg} \#$ and the $\mathrm{Fe}^{3+} /\left(\mathrm{Fe}^{3+}+\mathrm{Al}+\mathrm{Cr}\right)$ parameter. Symbols 1310 same as Figure 2. Analytical uncertainties associated with each composition lie within the 1311 symbol boundaries. 
1312 Figure 4: A) Equilibrium exchange coefficients calculated for opx and residual melt. B)

1313 Equilibrium exchange coefficients for opx and chromite. Symbols as in Figure 2.

1314 Figure 5: Results from MELTS and SPINMELT-2.0 modelling compared to experimental

1315 data (the edge of the ternary diagram from Figure $3 \mathrm{~A}$ is shown as a dashed line). Lines are

1316 drawn in the direction of decreasing temperature from $1200^{\circ} \mathrm{C}$ to $1100^{\circ} \mathrm{C}$. Solid symbols

1317 represent model data that do not account for iron loss, while empty symbols represent data

1318 generated using models with $30 \%$ imposed iron loss.

1319 Figure 6: Comparison between average chromite $\mathrm{Fe}^{2+} / \mathrm{Fe}^{3+}$ observed in experimental charges

1320 and modelled equilibrium glass values of the same ratio (grey lines). For equilibrium

1321 conditions to be met, the symbols for each sample would need to lie below the grey lines.

1322 Figure 7: Graphical representation of the chemical evolution of chromites within the

1323 compositional space of the spinel prism (inset). Hypothesized relationship: Fe-Mg

1324 interdiffusivity $>\mathrm{Fe}-\mathrm{Al}$ interdiffusivity $>\mathrm{Cr}$-(Al, $\mathrm{Fe})$ interdiffusivity. If $\mathrm{Fe}-\mathrm{Mg}$ and $\mathrm{Fe}-\mathrm{Al}$

1325 equilibrate chromite $\mathrm{Mg} \#, \mathrm{Fe}^{2+} / \mathrm{Fe}^{3+}$, and $\mathrm{Fe}^{3+} / \mathrm{Al}$, with $\mathrm{Cr}$ equilibration following, then re-

1326 equilibration is a process that may be approximated by reactions 1 and 2 in a multi-step

1327 fashion. A) Reaction 1 displaces chromite compositions to higher $\mathrm{Fe}^{2+} / \mathrm{Mg}$ and $\mathrm{Fe}^{3+} / \mathrm{Al}$ as the

1328 spinel (s.s.) component in chromite decreases. In ternary space, this reaction causes a shift to

1329 higher $\mathrm{Fe}^{3+}$ concentrations along lines of equal $\mathrm{Cr}$ proportion (B). Reaction 2 proceeds along

1330 lines of equal $\mathrm{Fe}^{3+} / \mathrm{Al}$ (dashed grey line in $\mathrm{B}$ ) as $\mathrm{Cr}$ is lost to the melt phase. Reaction 2

1331 proceeds in a direction perpendicular to the page (up) in A.

1332 Figure 8: Partial ternary diagrams (see inset) generated to compare trivalent cation

1333 proportions of natural chromite minerals from the Troodos ophiolite (green triangles) with

1334 modelled chromite compositions generated using SPINMELT-2.0. The grey-bordered green

1335 area underlying the green triangles on the Kalavassos Mine section represents the 
compositional range of olivine-hosted chromite inclusions taken from Golowin et al. (2017) and MacLeod (1988).

1338 Figure 9: Diagram summarizing the petrogenetic model wherein disequilibrium textures are

1339 preserved in phenocrystic-microphenocrystic chromite as a function of differences between

1340 the diffusivities of the major divalent and trivalent cations in chromite. A) Spinel octahedron.

1341 Subsequent images use a cross section of this hypothetical mineral form. B) A schematic of

1342 the initial condition of chromite in primitive boninite melt without a large proportion of

1343 silicate minerals. C) Silicate mineral nuclei form, immediately depleting the surrounding melt

1344 in $\mathrm{Fe}^{2+}$ and $\mathrm{Mg}$. D) Silicate minerals grow and completely alter the surrounding melt. The

1345 melt has acquired an evolved residual composition rich in $\mathrm{Fe}^{3+}$. E) Hypothetical diffusion

1346 trends for all major cations in chromite from a-a' (transect shown in D). 
Table 1: Starting material compositions

\begin{tabular}{|c|c|c|c|c|}
\hline & $\begin{array}{l}\text { High-Si Boninite } \\
\text { *YK0612 974-R6 }\end{array}$ & $\begin{array}{l}\text { Troodos Chromitite } \\
* * \text { Chromite Seed }\end{array}$ & $\begin{array}{l}\text { Boninite Glass } \\
\quad * * \mathrm{BO}-\mathrm{G}\end{array}$ & $\begin{array}{l}\text { Normalized Mixture Composition } \\
\text { BO-G with } 2 \mathrm{wt} \% \text { added Chromite }\end{array}$ \\
\hline $\mathrm{SiO}_{2}$ & 56.74 & 0.05 & 57.92 & 55.51 \\
\hline $\mathrm{TiO}_{2}$ & 0.17 & 0.05 & 0.04 & 0.17 \\
\hline $\mathrm{Cr}_{2} \mathrm{O}_{3}$ & $* * * 0.19$ & 53.81 & 0.19 & 1.26 \\
\hline $\mathrm{Al}_{2} \mathrm{O}_{3}$ & 10.66 & 15.11 & 10.69 & 10.73 \\
\hline $\mathrm{FeO}$ & 8.75 & 15.34 & 8.38 & 8.87 \\
\hline $\mathrm{MnO}$ & 0.23 & 0.24 & 0.16 & 0.23 \\
\hline $\mathrm{MgO}$ & 15.04 & 14.01 & 14.62 & 15.01 \\
\hline $\mathrm{CaO}$ & 5.54 & - & 6.16 & 5.42 \\
\hline $\mathrm{Na}_{2} \mathrm{O}$ & 2.01 & - & 1.86 & 1.97 \\
\hline $\mathrm{K}_{2} \mathrm{O}$ & 0.82 & - & 0.46 & 0.80 \\
\hline $\mathrm{P}_{2} \mathrm{O}_{5}$ & 0.03 & - & 0.08 & 0.03 \\
\hline Total & 100.18 & 98.72 & 100.48 & 100.00 \\
\hline
\end{tabular}

*Composition from Reagan et al. (2010, XRF Analysis)

**All analyses of starting materials are provided in the supplemental Tables S1 and S2

$* * *$ Converted from ppm $\mathrm{Cr}$ to $\mathrm{wt} \% \mathrm{Cr}_{2} \mathrm{O}_{3}$

$-=$ not quantified 
Table 2: Sample identification and characterization, experiment descriptions, and preliminary results

\begin{tabular}{lc|cc|cccc}
\hline Capsule ID & IHPV Lab & \multicolumn{2}{|c|}{ Initial Composition } & \multicolumn{4}{c}{ Experimental Conditions } \\
& & Seed Size $(\mu \mathrm{m})$ & $\mathrm{wt} \% \mathrm{D}_{2} \mathrm{O}(1 \sigma)$ & $\mathrm{T}\left({ }^{\circ} \mathrm{C}\right)$ & $\mathrm{P}(\mathrm{kbar})$ & $p \mathrm{H}_{2}$ added $(\mathrm{bars})$ & Duration (hrs) \\
\hline Bon1200Ua & ISTO & $\mathrm{x}<32$ & $1.136(0.142)$ & 1200 & 2.13 & 0.0 & 4.0 \\
Bon1200Ub & ISTO & $160<\mathrm{x}<250$ & $1.395(0.155)$ & 1200 & 2.13 & 0.0 & 4.0 \\
Bon1200Ba & ISTO & $\mathrm{x}<32$ & $0.916(0.153)$ & 1200 & 2.12 & 1.9 & 1.4 \\
Bon1200Bb & ISTO & $160<\mathrm{x}<250$ & $0.763(0.191)$ & 1200 & 2.12 & 1.9 & 1.4 \\
Bon1150U & ISTO & $\mathrm{x}<32$ & $0.770(0.128)$ & 1150 & 2.16 & 0.0 & 4.2 \\
Bon1150B & ISTO & $\mathrm{x}<32$ & $0.705(0.141)$ & 1150 & 2.14 & 1.4 & 3.2 \\
Bon1100U & GSJ & $\mathrm{x}<32$ & $1.280(0.142)$ & 1100 & 2.00 & 0.0 & 5.1 \\
\hline
\end{tabular}

Names: $U=$ intrinsic $f_{2}, B=$ buffered $f_{2}$, $a$ and $b$ designate a difference in the seed size of the chromite added

\section{Table 2 (continued)}

\begin{tabular}{|c|c|c|c|c|c|c|c|c|}
\hline \multirow[t]{2}{*}{ Capsule ID } & \multicolumn{3}{|c|}{ Product Phase Proportions $(1 \sigma)$} & \multicolumn{2}{|c|}{ Activity Model } & \multicolumn{3}{|c|}{ Oxygen Fugacity } \\
\hline & Orthopyroxene & Chromite & Glass & Final $w t \%{ }^{2} \mathrm{H}_{2} \mathrm{O}(1 \sigma)$ & $\mathrm{aH}_{2} \mathrm{O}(1 \sigma)$ & Sensor $X_{\mathrm{Ni}}(1 \sigma)$ & $\log f \mathrm{O}_{2}$ (bars) & $\Delta \mathrm{NNO}(1 \sigma)$ \\
\hline Bon1200Ua & $0.49(0.01)$ & $0.02(0.01)$ & $0.49(0.02)$ & $2.32(0.30)$ & $0.34(0.07)$ & $0.020(0.004)$ & -3.69 & $3.81(0.17)$ \\
\hline Bon $1200 \mathrm{Ba}$ & $0.59(0.07)$ & $0.01(0.00)$ & $0.40(0.07)$ & $2.29(0.55)$ & $0.31(0.11)$ & $0.256(0.003)$ & -6.77 & $0.73(0.26)$ \\
\hline Bon1200Bb & $0.55(0.01)$ & $0.01(0.01)$ & $0.44(0.01)$ & $1.73(0.44)$ & $0.22(0.08)$ & $0.256(0.003)$ & -7.07 & $0.43(0.27)$ \\
\hline Bon1150U & $0.40(0.08)$ & $0.02(0.00)$ & $0.58(0.08)$ & $1.33(0.29)$ & $0.17(0.07)$ & $0.020(0.004)$ & -4.88 & $3.21(0.29)$ \\
\hline
\end{tabular}


Table 3: Representative compositional data of experiment products (average composition)

\begin{tabular}{|c|c|c|c|c|c|c|c|c|c|c|c|c|c|c|c|c|c|}
\hline Sample & Phase & No. Analyses & $\mathrm{SiO}_{2}$ & $\mathrm{TiO}_{2}$ & $\mathrm{Cr}_{2} \mathrm{O}_{3}$ & $\mathrm{Al}_{2} \mathrm{O}_{3}$ & $\mathrm{FeO}$ & $\mathrm{MnO}$ & $\mathrm{MgO}$ & $\mathrm{CaO}$ & $\mathrm{Na}_{2} \mathrm{O}$ & $\mathrm{K}_{2} \mathrm{O}$ & $\mathrm{NiO}$ & Total & $\mathrm{Mg} \#$ & $\mathrm{Cr} \#$ & $* \mathrm{Fe}^{2+} / \mathrm{Fe}^{3+}$ \\
\hline \multirow[t]{3}{*}{ Bon1200Ua } & Glass & 6 & 61.36 & 0.07 & bdl & 16.34 & 5.90 & 0.10 & 2.43 & 6.51 & 3.08 & 0.81 & 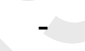 & 96.63 & - & - & 0.77 \\
\hline & Orthopyroxene & 15 & 55.99 & bdl & 0.69 & 1.66 & 6.59 & 0.20 & 33.87 & 1.09 & bdl & - & - & 100.14 & 0.90 & 0.22 & - \\
\hline & Chromite & 4 & 0.27 & bdl & 48.62 & 8.49 & 24.89 & 0.36 & 12.57 & - & - & - & 0.10 & 95.36 & 0.47 & 0.79 & 1.17 \\
\hline \multirow[t]{2}{*}{ Bon $1200 \mathrm{Ub}$} & Glass & 8 & 60.57 & 0.20 & bdl & 15.98 & 7.51 & 0.14 & 2.79 & 6.11 & 2.52 & 0.69 & - & 96.52 & - & - & 0.76 \\
\hline & Orthopyroxene & 13 & 56.35 & bdl & 0.67 & 1.49 & 6.09 & 0.18 & 34.30 & 0.93 & bdl & - & - & 100.04 & 0.91 & 0.23 & - \\
\hline \multirow[t]{2}{*}{ Bon1200Ba } & Glass & 5 & 62.08 & 0.18 & bdl & 17.90 & 5.24 & 0.13 & 1.64 & 6.13 & 2.99 & 0.84 & - & 97.17 & - & - & 3.35 \\
\hline & Orthopyroxene & 13 & 56.34 & bdl & 0.71 & 1.88 & 7.31 & 0.20 & 32.68 & 1.32 & 0.05 & - & - & 100.50 & 0.89 & 0.22 & - \\
\hline \multirow[t]{3}{*}{ Bon $1200 \mathrm{Bb}$} & Glass & 2 & 60.95 & 0.18 & bdl & 18.14 & 5.13 & 0.14 & 1.11 & 6.16 & 2.92 & 0.84 & - & 95.56 & - & - & 3.84 \\
\hline & Orthopyroxene & 9 & 54.99 & bdl & 0.68 & 1.56 & 7.18 & 0.20 & 32.28 & 1.20 & 0.15 & - & - & 98.25 & 0.89 & 0.23 & - \\
\hline & Chromite & 4 & 0.12 & 0.05 & 50.66 & 14.36 & 16.20 & 0.29 & 13.16 & - & - & - & 0.11 & 95.02 & 0.59 & 0.70 & 3.48 \\
\hline \multirow[t]{4}{*}{ Bon1150U } & Glass & 4 & 58.52 & 0.06 & 0.05 & 14.47 & 7.04 & 0.11 & 6.12 & 8.13 & 2.59 & 0.65 & - & 97.74 & - & - & 1.00 \\
\hline & Orthopyroxene & 8 & 55.02 & bdl & 0.64 & 2.47 & 8.46 & 0.23 & 31.23 & 1.69 & 0.06 & - & - & 99.84 & 0.87 & 0.15 & - \\
\hline & Chromite-Core & 4 & 0.11 & 0.04 & 51.17 & 11.86 & 21.57 & 0.39 & 11.62 & - & - & - & 0.12 & 96.95 & 0.49 & 0.74 & 2.44 \\
\hline & Chromite-Rim & 3 & 0.15 & bdl & 48.96 & 9.34 & 26.09 & 0.38 & 10.89 & - & - & - & 0.15 & 96.07 & 0.43 & 0.78 & 1.61 \\
\hline \multirow[t]{3}{*}{ Bon1150B } & Glass & 3 & 60.34 & 0.08 & bdl & 16.20 & 5.21 & 0.10 & 4.63 & 7.01 & 2.94 & 0.75 & - & 97.29 & - & - & 2.74 \\
\hline & Orthopyroxene & 2 & 54.98 & bdl & 0.70 & 2.37 & 9.04 & 0.24 & 31.57 & 1.89 & bdl & - & - & 100.83 & 0.86 & 0.16 & - \\
\hline & Chromite & 1 & 0.08 & 0.05 & 51.93 & 14.45 & 19.41 & 0.35 & 11.5 & - & - & - & 0.10 & 97.93 & 0.51 & 0.71 & 4.51 \\
\hline \multirow[t]{3}{*}{ Bon1100U } & Glass & 5 & 58.96 & 0.18 & 0.14 & 14.75 & 6.11 & 0.13 & 5.97 & 8.18 & 2.59 & 0.68 & - & 97.71 & - & - & 1.31 \\
\hline & Orthopyroxene & 3 & 55.20 & 0.05 & 0.44 & 3.33 & 9.13 & 0.29 & 30.01 & 2.67 & 0.10 & - & - & 101.24 & 0.85 & 0.08 & - \\
\hline & Chromite & 6 & 0.07 & 0.14 & 50.93 & 14.41 & 22.28 & 0.32 & 10.96 & - & - & - & 0.09 & 99.42 & 0.47 & 0.70 & 3.50 \\
\hline
\end{tabular}

*Calculated using either stoichiometric recalculation (after Droop, 1987) for chromite or the model of Kress and Carmichael (1991) for glass bdl = below detection limit,$-=$ not analyzed/calculated 
1352 Table 4: Predicted and observed equilibrium compositional data for orthopyroxene (opx) and chromite (chrm)

\begin{tabular}{|c|c|c|}
\hline Modelled & $\underline{K}_{D}(F e-M g)^{o p x-l i q}(1 \sigma)$ & ${ }^{*} K_{D}(F e-M g)^{c h r m-o p x}$ \\
\hline Bon1200Ua & $0.209(0.007)$ & 4.594 \\
\hline Bon1200Ub & $0.211(0.003)$ & - \\
\hline Bon1200Ba & $0.201(0.005)$ & - \\
\hline Bon $1200 \mathrm{Bb}$ & $0.199(0.002)$ & 4.639 \\
\hline Bon1150U & $0.233(0.001)$ & 4.936 \\
\hline Bon1150B & $0.219(0.003)$ & 4.957 \\
\hline Bon1100U & $0.231(0.009)$ & 5.098 \\
\hline \multicolumn{3}{|l|}{ Observed } \\
\hline Bon1200Ua & $0.080(0.004)$ & $5.475(0.260)$ \\
\hline Bon1200Ub & $0.066(0.003)$ & - \\
\hline Bon1200Ba & $0.070(0.005)$ & - \\
\hline Bon1200Bb & $0.048(0.001)$ & $4.279(0.110)$ \\
\hline Bon1150U & $0.236(0.011)$ & $5.103(0.237)$ \\
\hline Bon1150B & $0.246(0.013)$ & $4.863(0.238)$ \\
\hline Bon1100U & $0.298(0.010)$ & $5.194(0.171)$ \\
\hline
\end{tabular}


Table 5: Assessment of Fe-Mg equilibrium between opx, chromite, and melt in Kapilio lavas

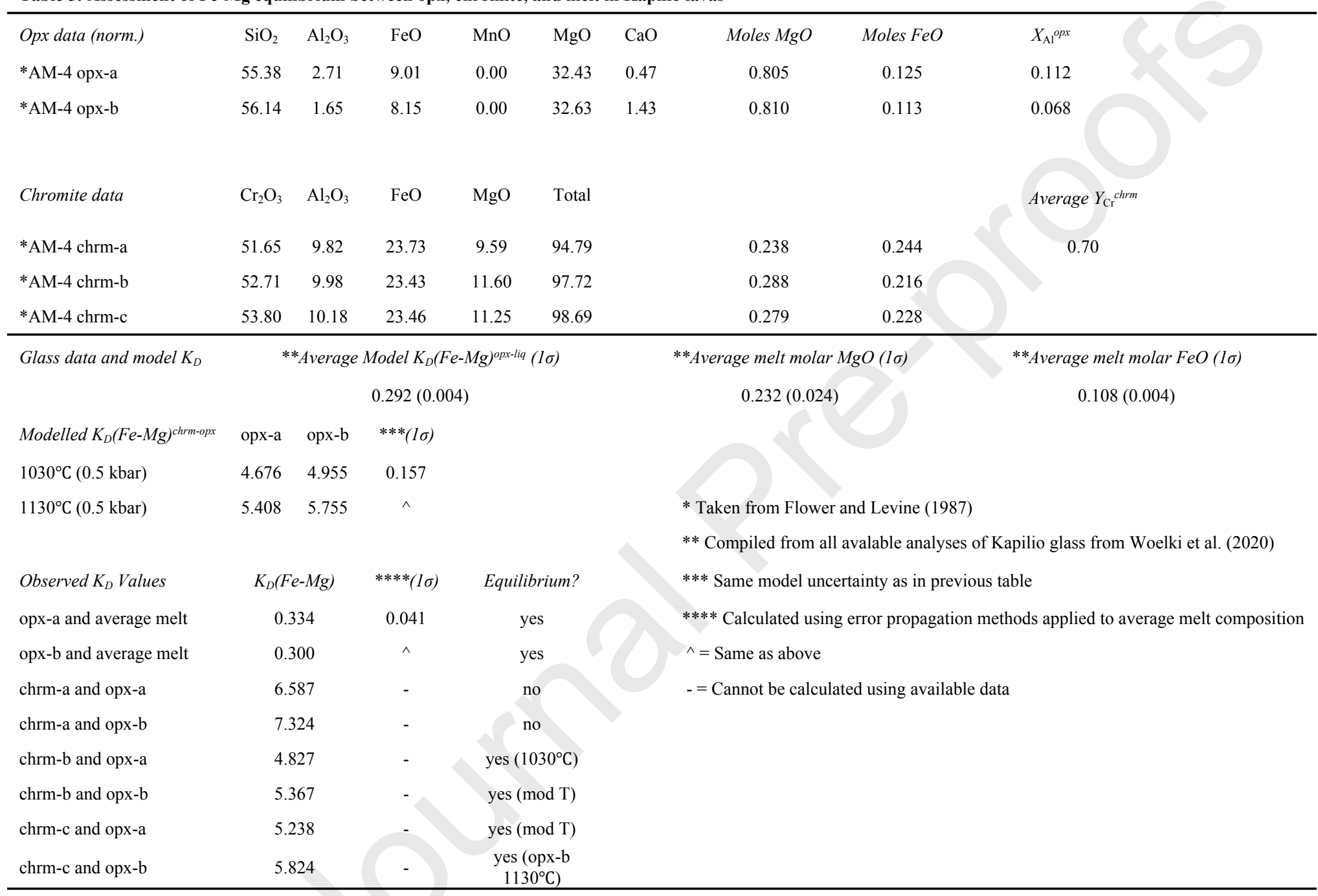


Table 6: Ascent time calculations

\begin{tabular}{|c|c|c|c|c|}
\hline \multirow[t]{2}{*}{ Chromite Radius $(\mu m)$} & \multicolumn{2}{|c|}{ Maximum Ascent Time from Cr-Al Diffusion (years) } & \multicolumn{2}{|c|}{ Minimum Ascent Time from Fe-Mg Diffusion (days) } \\
\hline & at $1030^{\circ} \mathrm{C}$ & at $1130^{\circ} \mathrm{C}$ & at $1030^{\circ} \mathrm{C}$ & at $1130^{\circ} \mathrm{C}$ \\
\hline 15 & 43 & 2 & 56 & 15 \\
\hline 20 & 77 & 4 & 99 & 27 \\
\hline 25 & 120 & 6 & 155 & 42 \\
\hline 30 & 173 & 8 & 223 & 60 \\
\hline $\log D\left(\mathrm{~cm}^{2} / \mathrm{sec}\right)$ & -16.2 & -14.9 & -12.7 & -12.2 \\
\hline
\end{tabular}




\section{Declaration of interests}

$\bigotimes$ The authors declare that they have no known competing financial interests or personal relationships that could have appeared to influence the work reported in this paper.

$\square$ The authors declare the following financial interests/personal relationships which may be considered as potential competing interests:

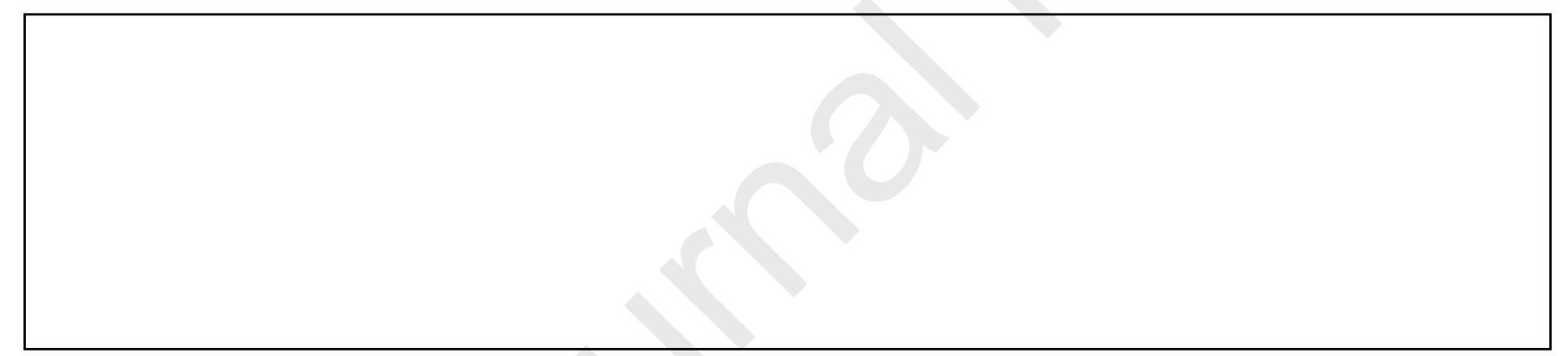

